\title{
Sedimentation in Brownell
}

Creek Subwatershed No. 1

Nebraska

GEOLOGICAL SURVEY WATER-SUPPLY PAPER 1798-C

Prepared in cooperation with the U.S. Department of Agriculture Soil Conservation Service

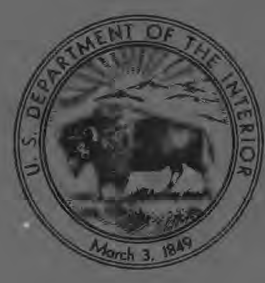

U. S. GEOLOGICAL SURVE: WATER RESOIIRTES NIVISIN"

NoV 11966 


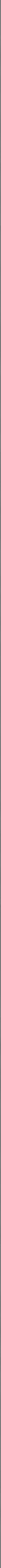




\section{Sedimentation in Brownell}

Creek Subwatershed No. 1

\section{Nebraska}

y JAMES C. MUNDORFF

EDIMENTATION IN SMALL DRAINAGE BASINS

EOLOGICAL SURVEY WATER-SUPPLY PAPER 1798-C

repared in cooperation with the

J.S. Department of Agriculture

oil Conservation Service

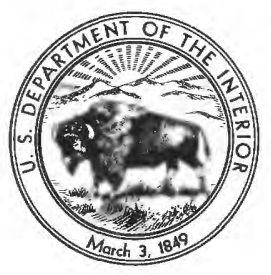


UNITED STATES DEPARTMENT OF THE INTERIOR

STEWART L. UDALL, Secretary

GEOLOGICAL SURVEY

William T. Pecora, Director 


\section{CONTENTS}

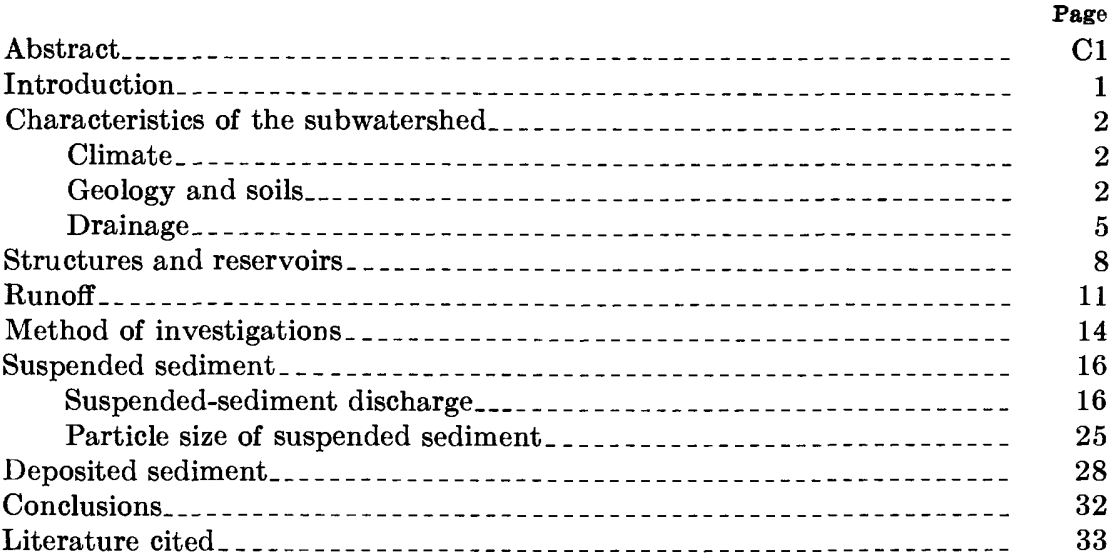

\section{ILLUSTRATIONS}

Plate 1. Map showing land use in Brownell Creek subwatershed, 1955-59

In pocket

Figure 1. Map of Brownell Creek subwatershed.

2. Block diagram of part of Brownell Creek subwatershed showing the relation of soils to geology and physiographic position

3. Photograph of channel upstream from northeast corner

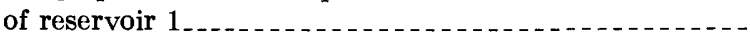

4. Sketch showing runoff pattern under natural conditions and terrace conditions in part of the subwatershed....

5-11. Photographs showing:

5. Preconstruction site of reservoir 1...

6. Reservoir 1.

7. Reservoir 1A

8. Large dam about 300 feet upstream from county bridge

9. Discharge tube, reservoir $1 \mathrm{~A}$

10. Outflow from discharge tube, reservoir 1 $\ldots \ldots$

11. Partly submerged vertical stack of automatic suspended-sediment samplers at trash rack, reservoir 1

12. Graph showing water discharge, accumulated rainfall, and suspended-sediment concentration, reservoir 1, June 23-25, 1955 
FIGURE 13. Graph showing reservoir gage height, accumulated rainfall, and suspended-sediment concentration, reservoir 1A, June 23-24, 1955 ..............................

14. Photograph of Brownell Creek subwatershed......... Page

15-17. Graphs showing water discharge, accumulated rainfall, and suspended-sediment concentration, reservoir 1:

15. June 28-29, 1955

16. July 31-Aug. 1, $1956 \ldots$

17. Aug. 18, 1956

18-20. Graphs showing gage height, accumulated rainfall, suspended-sediment concentration, and water discharge, reservoir 1:

18. July 9-10, 1958

19. Aug. 5-7, 1958

20. May 2-4, 1959 26

21. Trilinear diagram showing percentage of clay, silt, and sand in samples from Brownell Creek subwatershed --

22. Graph showing relation of percentage of clay to suspended-sediment concentration, inflow to reservoirs 1 and 1 A . . . . . . . . . . . . .

23. Map showing locations of sampling sections for deposited

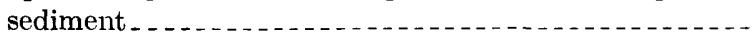

24. Graph showing relation of bulk density to percentage of

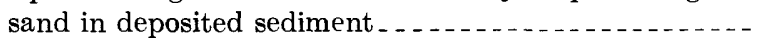

\section{TABLES}

TABLE 1. Area and capacity of reservoir 1 from survey of March 1955.

2. Area and capacity of reservoir $1 \mathrm{~A}$ from survey of March 1955.

3. Reservoir discharge and other hydrologic data, reservoirs 1 and $1 \mathrm{~A}_{\ldots} \ldots$

4. Hydrologic data, Brownwell Creek subwatershed No. 1,

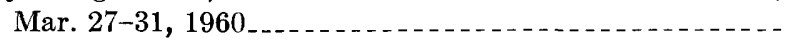

5. Summary of outflow from reservoir $1,1955-59 \ldots \ldots$

6. Summary of outflow from reservoir 1A, 1955-59

7-10. Particle-size analyses of suspended sediment:

7. Inflow to reservoir $1 \ldots$

8. Inflow to reservoir $1 \mathrm{~A}_{\ldots} \ldots$

9. Outflow from reservoir $1 \mathrm{~A}$

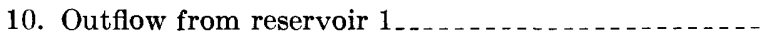

11. Bulk density and particle-size distribution of samples of deposited sediment in reservoirs 1 and 1A, 1958........

12. Particle-size distribution of deposited-sediment samples in channel and in reservoir 1, Feb. 19, 1957.

13. Chemical analyses, Brownell Creek subwatershed near Syracuse. 


\section{GLOSSARY}

Automatic suspended-sediment sampler. A bottle that is equipped with intake nozzle and exhaust tube, that is mounted in a fixed position, and that admits water-sediment mixture when the water rises to the Ievel of the nozzle.

Drainage density. The ratio of the total length of all drainage channels to the drainage area.

Flocculation. The formation of a large sediment aggregate caused by the coalescence of small particles that are subjected to certain physicochemical conditions.

Instantaneous suspended-sediment discharge. The rate at which dry weight of suspended sediment passes a section of a stream or conduit at a given instant.

Particle-size classification. In this report the classification is, unless otherwise noted, as follows: Sand, $0.062-2.0 \mathrm{~mm}$; silt, $0.004-0.062 \mathrm{~mm}$; clay, less than $0.004 \mathrm{~mm}$.

Percent sodium. The ratio, expressed in percentage, of sodium to the sum of the positively charged ions (calcium, magnesium, sodium, and potassium) all ions in equivalents per million.

Relief ratio. The ratio of the maximum relief in a basin to the longest dimension of the basin parallel to the principal drainage line (Schumm, 1956).

Sodium-adsorption-ratio. A ratio for soil extracts and irrigation waters, used to express the relative activity of sodium ions in exchange reactions with soil.

$$
\mathbf{S A R}=\frac{\mathrm{Na}^{+}}{\sqrt{\frac{\mathrm{Ca}^{+2}+\mathrm{Mg}^{+2}}{2}}}
$$

The ionic concentrations are expressed in equivalents per million.

Suspended-sediment concentration. The weight of dry sediment per unit weight of water-sediment mixture, expressed in parts per million.

Trap efficiency. The ratio, expressed as a percentage, of the weight of sediment retained in a reservoir to the weight of sediment entering the reservoir. 


\title{
SEDIMENTATION IN BROWNELL CREEK SUBWATERSHED NO. 1, NEBRASKA
}

\author{
By James C. Mundorf
}

\begin{abstract}
This report presents the results of a sedimentation investigation in Brownell Creek subwatershed No. 1 which was made as part of a nationwide investigation of the trap efficiency of detention reservoirs. The subwatershed is in southeastern Nebraska, has a drainage area of 495 acres, receives an average of 28.75 inches of precipitation annually, has a total relief of about 95 feet, and has a surface mantle composed mainly of loess and glacial till.

Average annual runoff, based on records of precipitation and reservoir discharge and on estimates of reservoir evaporation and seepage loss, was 3.3 inches during 1955-59. Precipitation ranged from significantly below normal in 1955 and 1956 to appreciably above normal in 1957-59.

Most of the sediment transported into reservoirs 1 and $1 \mathrm{~A}$ is silt and clay; generally, less than 10 percent of the suspended sediment is sand. Of the total sediment that enters reservoir 1, all the sand and much of the silt and clay are trapped. Trap efficiency of this reservoir, computed from partly estimated data, was between 90 and 95 percent during 1955-59.

During 1955-59, total sediment discharge from reservoir 1 was about 400 tons, of which 135 tons was discharged during the period June 24-26, 1955. About 77 percent of the sediment from reservoir 1 was discharged during seven outflow periods, each of which was less than 5 days in duration.
\end{abstract}

\section{INTRODUCTION}

The Geological Survey, in cooperation with the Soil Conservation Service, began an investigation of sedimentation in Brownell Creek subwatershed No. 1 in 1955. This investigation is part of a nationwide investigation of the trap efficiency of detention reservoirs; it was conducted under the general supervision of P. C. Benedict, regional engineer, to 1957 and D. M. Culbertson, district engineer, after 1957.

Records of water discharge were furnished for 1955 and 1956 by D. D. Lewis, district engineer, and for 1957-60 by F. F. LeFever, district engineer. Records of precipitation were furnished by the U.S. Weather Bureau. Valuable information on land use, land treatment measures, and structures was furnished by Gene O'Donnell and R. R. Hraban, Work Unit Conservationists of the Soil Conservation Service. Information on reservoir stage-capacity relations and on bulk density and particle-size distribution of deposited sediment was furnished by H. G. Heinemann, hydraulic engineer, of the Agricultural Research Service. 


\section{CHARACTERISTICS OF THE SUBWATERSHED}

Brownell Creek subwatershed No. 1, one of many subwatersheds that compose Brownell Creek watershed, is in the central part of Otoe County, Nebr. (fig. 1), and is part of the Dissected Till Plains of eastern Nebraska. The drainage area of the subwatershed is approximately 495 acres.

\section{CLIMATE}

The climate of Brownell Creek subwatershed and of southeastern Nebraska is continental and subhumid. At Syracuse, the long-term mean temperatures are about $25^{\circ} \mathrm{F}$ for January and about $79^{\circ} \mathrm{F}$ for July. Since about 1900 , the range in temperature has been nearly $150^{\circ} \mathrm{F}$; a maximum of $116^{\circ} \mathrm{F}$ and a minimum of $-33^{\circ} \mathrm{F}$ have been recorded. The growing season is usually 160-170 days.

The long-term average annual precipitation at Syracuse is 28.75 inches. On the average, about 55 percent of the total annual precipitation occurs from May to August, and about 75 percent from April to September. During 1955-59 the annual precipitation averaged about 30.3 inches; in 1955 and 1956 it was significantly below normal, and in 1957-59 it was significantly above normal.

Precipitation in Brownell Creek subwatershed was measured at a recording gage near the south side of the subwatershed and at a nonrecording gage near the northeastern part of the subwatershed. (See fig. 1.) The available records for these gages extend back only to July 1956. For 1957, 1958, and 1959, the total annual precipitation reported in the subwatershed was significantly less than that reported at a recording gage and a nonrecording gage about 3 miles to the west at Syracuse. Differences in gage maintenance and reporting techniques may be responsible for some of the discrepancy. The discrepancy between the data for the recording gages was appreciably less than that between the data for the nonrecording gages.

Most of the rainfall and runoff are a result of warm-season thunderstorms. For any particular storm, rainfall variability is high even in small areas; therefore, data from the two precipitation gages in the subwatershed give only a general indication of the quantity and distribution of precipitation over the area.

At Syracuse, precipitation events exceeding 0.25 inch occur, on the average, about 31 times a year, and those exceeding 1.0 inch about 7 times.

\section{GEOLOGY AND SOILS}

Deposits of Pleistocene age mantle the subwatershed. Peorian Loess, of late Pleistocene age, forms a nearly continuous mantle over the eastern half of the area and is on divide areas and upper slopes 


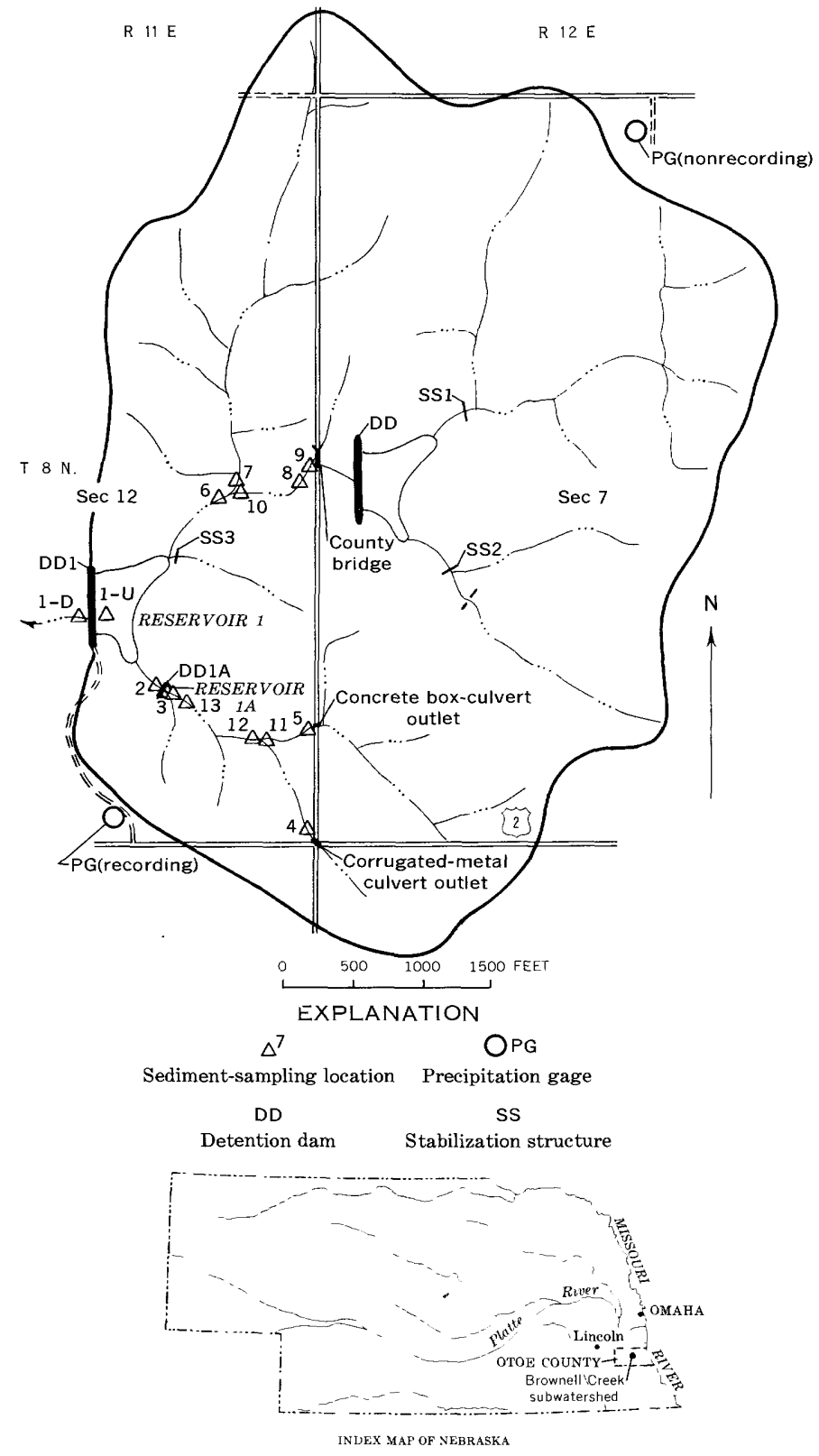

Figure 1.-Brownell Creek subwatershed. 
in the western half of the area. Loveland Loess, which underlies the Peorian Loess in this southeastern Nebraska area, is not exposed to any significant extent. Kansan Drift, also of Pleistocene age, is generally exposed on moderate to steep slopes in the western part of the subwatershed. The Kansan Drift, which is stratigraphically lower than the Peorian and Loveland Loess, is also topographically lower in most places. Late Pleistocene to Recent alluvium mantles the small, narrow bottomland areas.

Soil development in the subwatershed varies mainly with parent material, physiographic position, and slope. Because climate and regetation conditions under which soils developed in this small drainage basin were relatively homogeneous, they were unimportant determinants of profile differences. Soils developed on loess are predominant in the eastern half of the area and grade into mainly glacialtill soils in the western part of the subwatershed. Slope, infiltration rate, soil permeability, and parent material may vary within small areas. Severe erosion has exposed the B horizon in small areas of steeply sloping land.

A soil survey of Otoe County, Nebr. (Beesley and others, 1950), indicates that 61.6 percent, or 305 acres, of the subwatershed is occupied by soils of the Sharpsburg series, which are developed on Peorian Loess. Of the 305 acres, about 155 acres is Sharpsburg silty clay loam; 112 acres is Sharpsburg silty clay loam, rolling phase; and 38 acres is Sharpsburg silty clay loam, eroded rolling phase. About 29.3 percent, or 145 acres, of the subwatershed is occupied by soils of the Carrington series, ${ }^{1}$ which are developed on glacial till. Of the 145 acres, about 5 acres is Carrington clay loam; 125 acres is Carrington clay loam, eroded rolling phase; and 15 acres is Carrington loam, eroded rolling phase. Soils of the Burchard-Carrington complex, developed on glacial till, occupy about 2.0 percent of the subwatershed. The JudsonWabash complex, developed on colluvial-alluvial material, occupies about 7.1 percent of the subwatershed. Figure 2 shows the relation between soils, parent material, physiographic position, and slope.

Most of the drainage area is under cultivation; corn, sorghum, wheat, and oats are the main crops. Much of the steeply sloping land is in native grass or is seeded to grasses and legumes; small areas of native grass are along the major channels. Nearly all the minor drainageways have been seeded to grass to prevent gully formation. Plate 1 shows the general kinds of land use during $1955-59$; these uses are indicative of the diversity of crops and of the rotation system commonly used in the subwatershed. The lack of quantitative data on

\footnotetext{
${ }^{1}$ In November 1959, the Carrington soil series was discontinued; the present (1962) equivalent of the Carrington in eastern Nebraska is generally the Shelby series (A. R. Aandahl, oral commun., 1962).
} 
EXPLANATION

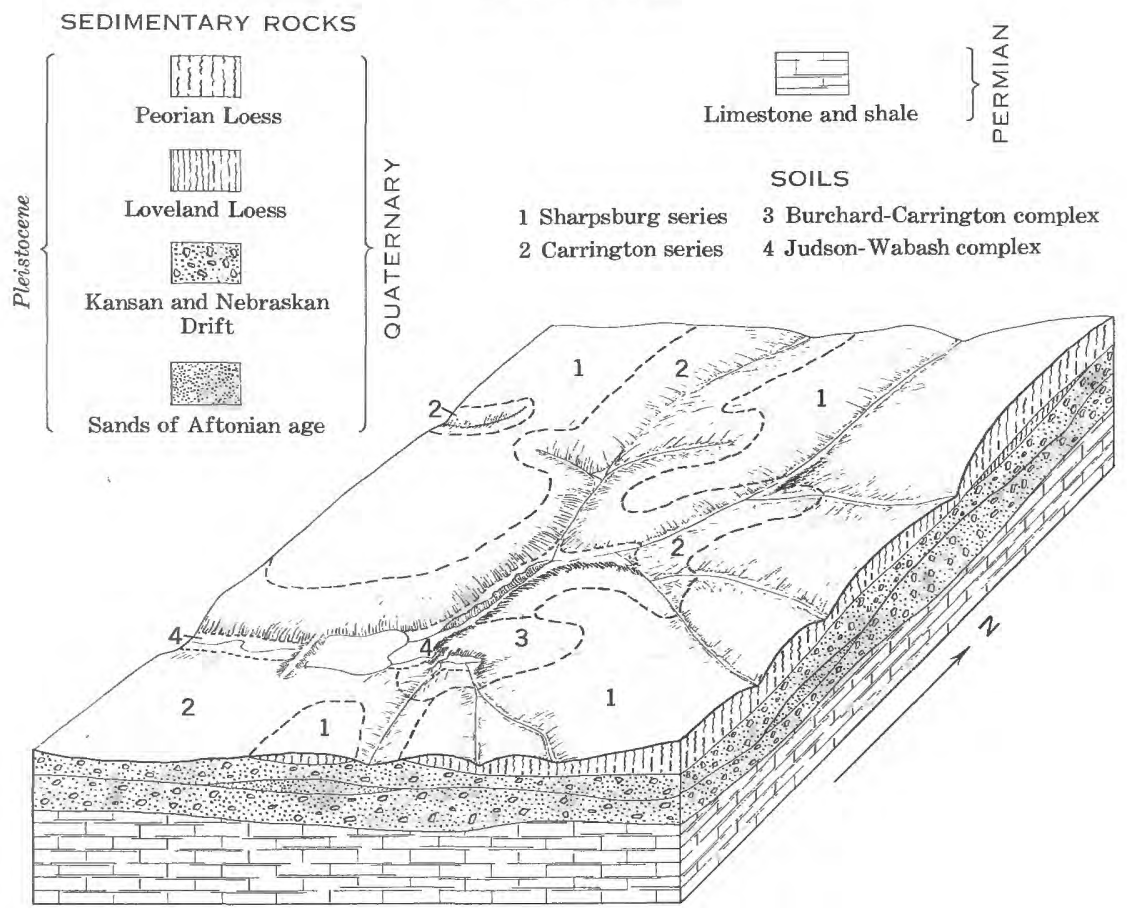

FIGURE 2.-Part of Brownell Creek subwatershed showing the relation of soils to geology and psysiographic position. Subsurface geology is inferred. Area shown is about 450 acres.

sediment yield from different parts of the subwatershed upstream from reservoirs 1 and $1 \mathrm{~A}$ prevents the establishment of the relation of land use to sediment yield from any specific part of the subwatershed during any given year or any given storm. The establishment of this relation would require not only quantitative sediment data but also detailed analysis of the reason why certain creps are grown on a specific area, of the roadside erosion and the natural channel erosion in the subwatershed, of the earthmoving and construction operations in the subwatershed during the period of investigations, of the type of tillage practices, of the type and intensity of precipitation relative to the season and to the type and density of soil cover, of the presence or absence of soil frost during any given storm, and of the natural differences in erodibility of the surface materials that mantle the subwatershed.

\section{DRAINAGE}

Total relief within the drainage area is about 95 feet. Slopes generally are 4-12 percent and range from 100 to 800 feet in length. 
The major natural channels of the dendritic drainage system have very steep or vertical banks. The main channel leading into the northeast comer of reservoir 1 is incised $4-8$ feet below the flood plain. (See fig. 3.) Graded terraces that are constructed on most of the cultivated land and on some of the pastureland have modified the natural runoff pattern on most of the subwatershed. Figure 4 shows the general runoff pattern under both natural and terrace conditions on about 60 acres adjacent to reservoirs 1 and $1 \mathrm{~A}$. The terraces affect surface runoff in two ways: the runoff travels farther and at a lower gradient than the runoff would under natural conditions, and the runoff from any given point in a terraced area generally enters the main channels farther upstream than the runoff would under natural conditions. The drainage area of reservoir $1 \mathrm{~A}$ is larger under terrace conditions than under natural conditions because runoff that would naturally flow directly into reservoir 1 is caused to enter the channel upstream from reservoir $1 \mathrm{~A}$.

Prior to the construction of reservoir 1, the channel that drains the north 370 acres of the subwatershed joined the channel that drains the south 125 acres near the center of the present reservoir site. (See fig. 5.) The present main north channel is a fourth-order stream, and

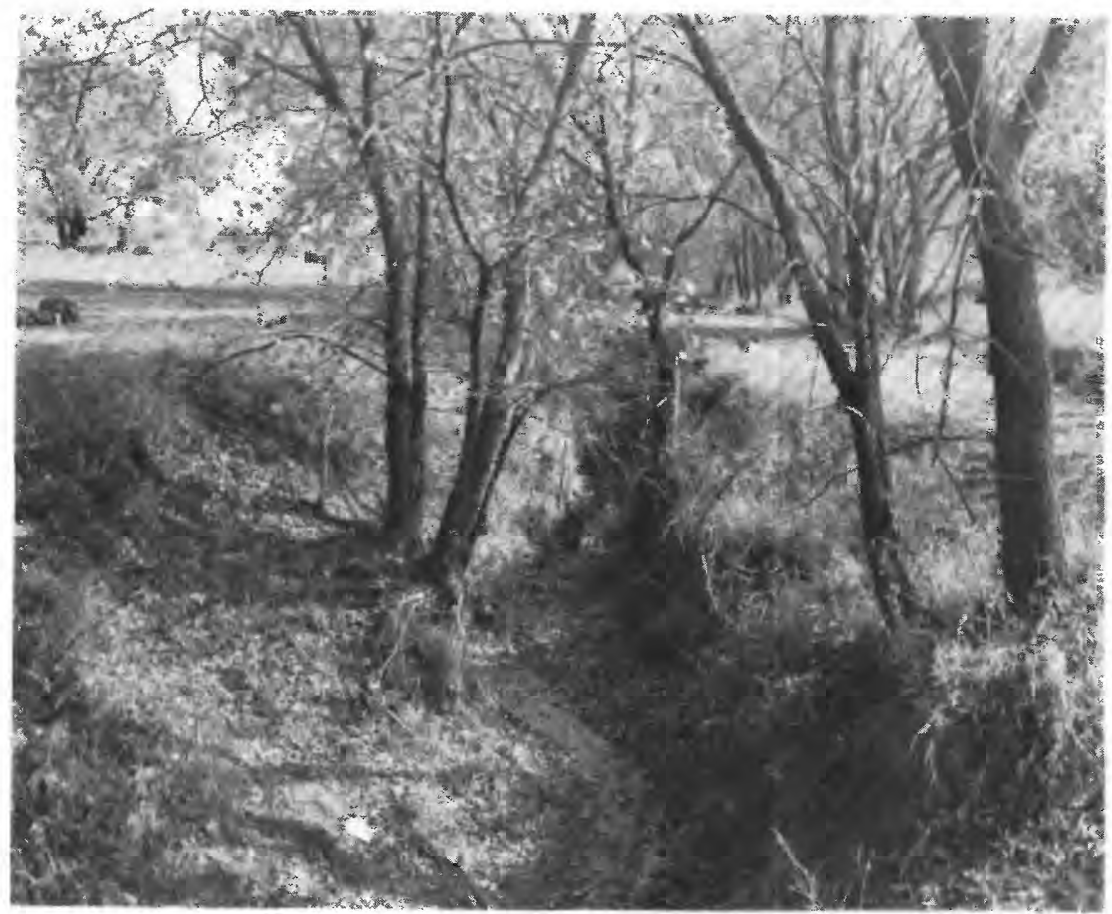

Frgure 3.-Channel upstream from northeast corner of reservoir 1. 

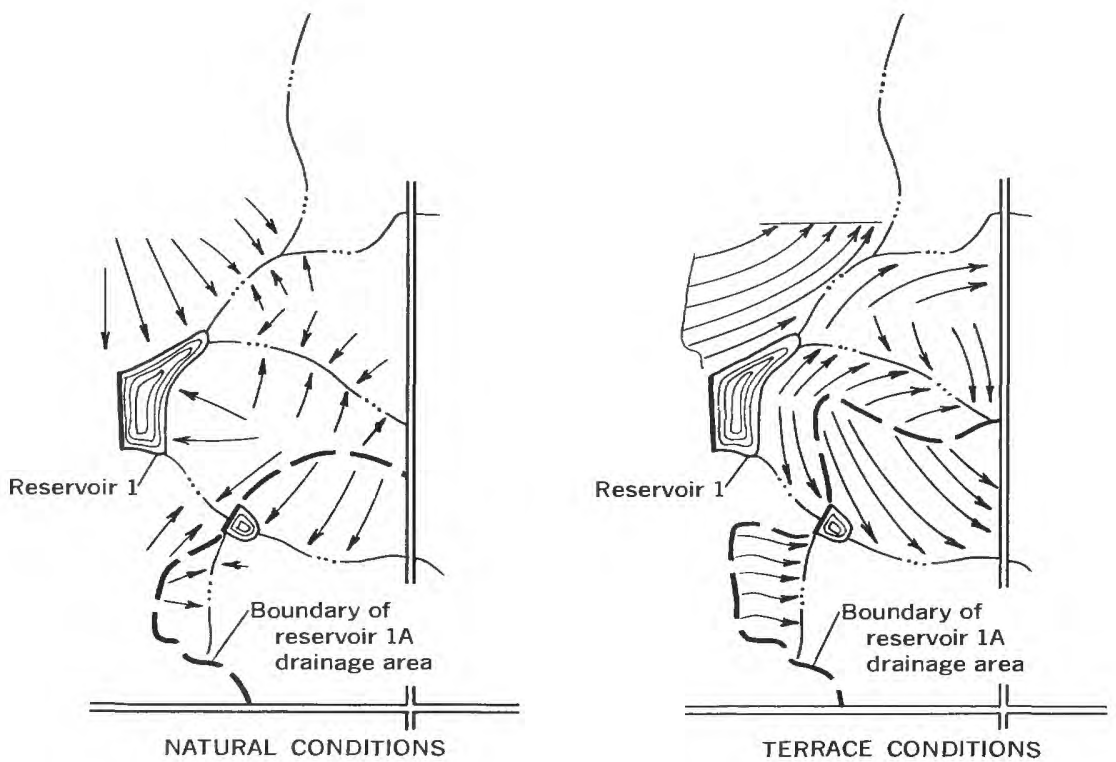

Figure 4.-Runoff pattern under natural conditions and under terrace conditions in part of the subwatershed.

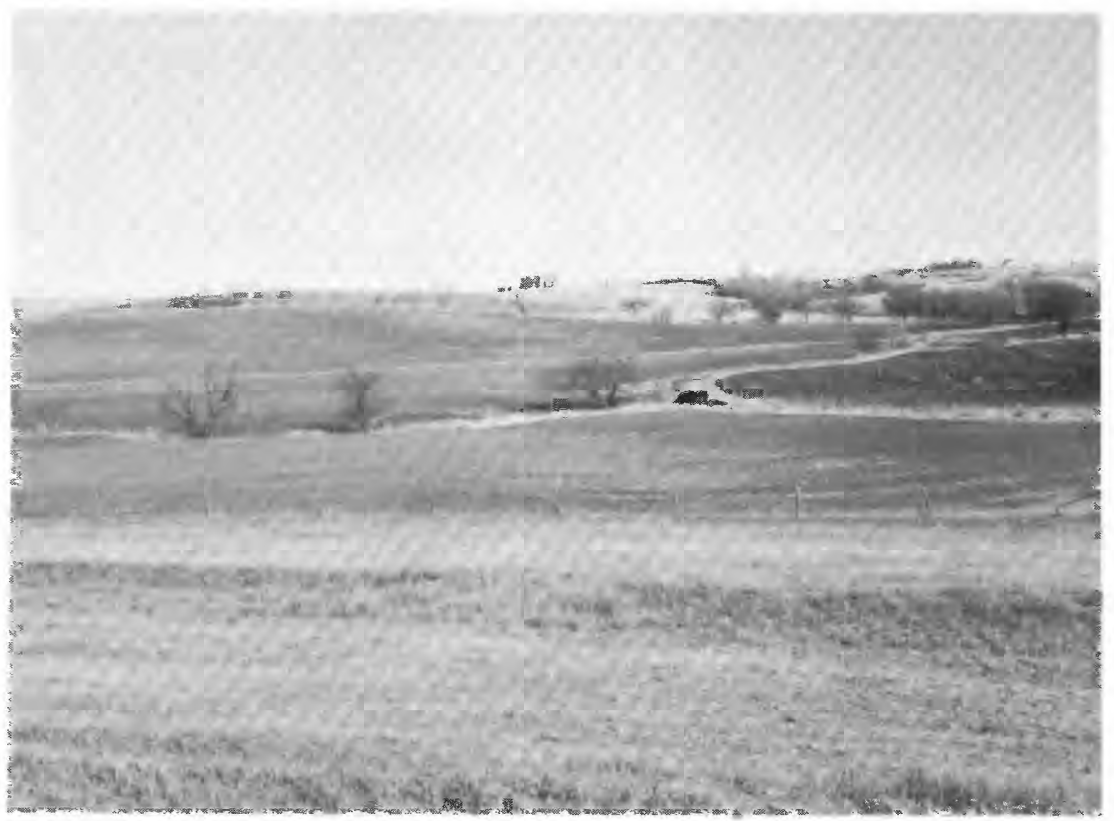

FIGURE 5.-Looking north across preconstruction site of reservoir 1. Photograph by Soil Conservation Service. 
the main south channel is a third-order stream. The method described by Strahler (1952) was used in determining stream order: the smallest, or "fingertip," channels are the first-order segments, the junction of any two first-order streams form a second-order segment, the junction of any two second-order streams form a third-order segment, and so on.

Relief ratio for the subwatershed is about 0.018 . Natural drainage density was 7.3 ; present drainage density may be slightly different because of routing of runoff from terraced areas and because of the obliteration of some first-order channels during tillage operations and terrace construction. If each graded terrace is regarded as a channel, then the drainage density is probably increased at least fourfoldto 30 or more.

\section{STRUCTURES AND RESERVOIRS}

In 1955 , reservoir 1 (fig. 6), which was completed in 1954, had a capacity of 125.6 acre-feet and a surface area of 16.0 acres at the crest of the emergency. spillway (elevation 1,144 ft. above mean sea level) and a capacity of 30.5 acre-feet and a surface area of 5.0 acres at the top of the drop inlet (elevation 1,134 ft). Table 1 gives the area and capacity at 1-foot increments of elevation for this reservoir.

In 1955, reservoir 1A (fig. 7), which was completed several years before reservoir 1 , had a capacity of 4.25 acre-feet and a surface area of 1.29 acres at the crest of the emergency spillway (elevation 1.152 $\mathrm{ft}$ above mean sea level) and a capacity of 1.94 acre-feet and a surface area of 0.6 acres at the top of the drop inlet (elevation 1,149.34 ft). Table 2 gives the area and capacity for this reservoir.

Stabilization structures 1, 2, and 3 exert a minor control on runoff and sediment discharge from part of the subwatershed.

In May 1959, a large dam was completed about 300 feet upstream from the county bridge. (See figs. 1, 8.) This large upstream reservoir now detains or stores runoff from about 230 acres. It has a capacity of 14.3 acre-feet and a surface area of 3.5 acres at drawdown elevation of $1,167.5$ feet above mean sea level. The capacity is 24.9 acre-feet and the surface area is 5.04 acres at the riser elevation of 1,170 feet; the capacity is 58.6 acre-feet and the surface area is 8.76 acres at the crest of the emergency spillway, elevation 1,175 feet. Outflow from this reservoir begins when the reservoir stage reaches a horizontal inlet, which is about 8 inches in diameter and which taps into the riser of a drop inlet of 24 inches in diameter. The top of the riser is about 2.5 feet higher than the top of the 8-inch drawdown tube. The discharge tube has a circular opening 18 inches in diameter. 


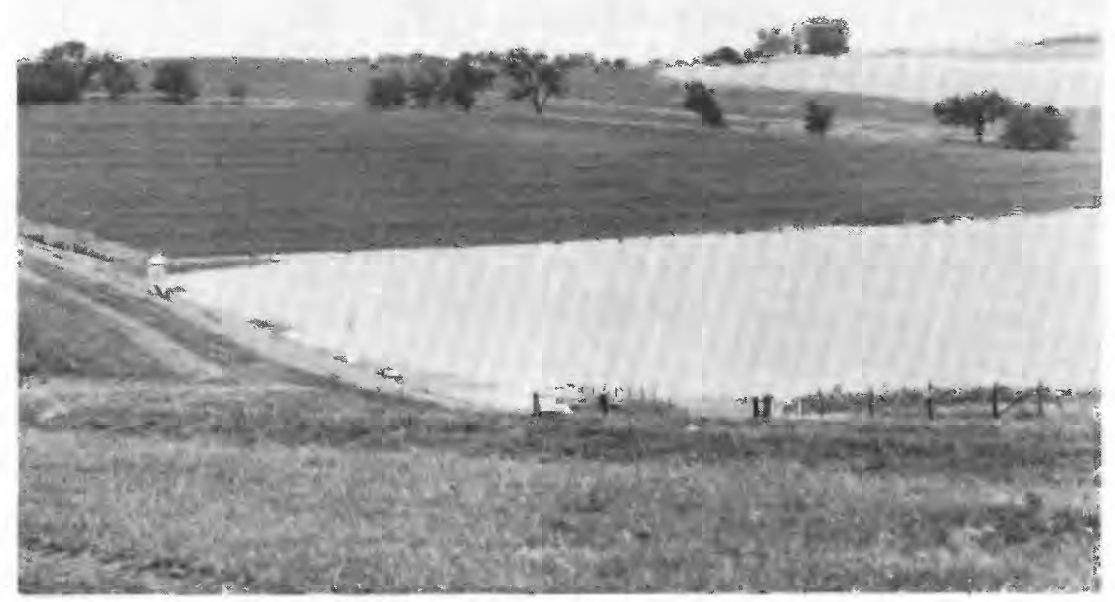

Figure 6.-Reservoir 1 (June 24, 1955, reservoir elevation about 1,140 ft).

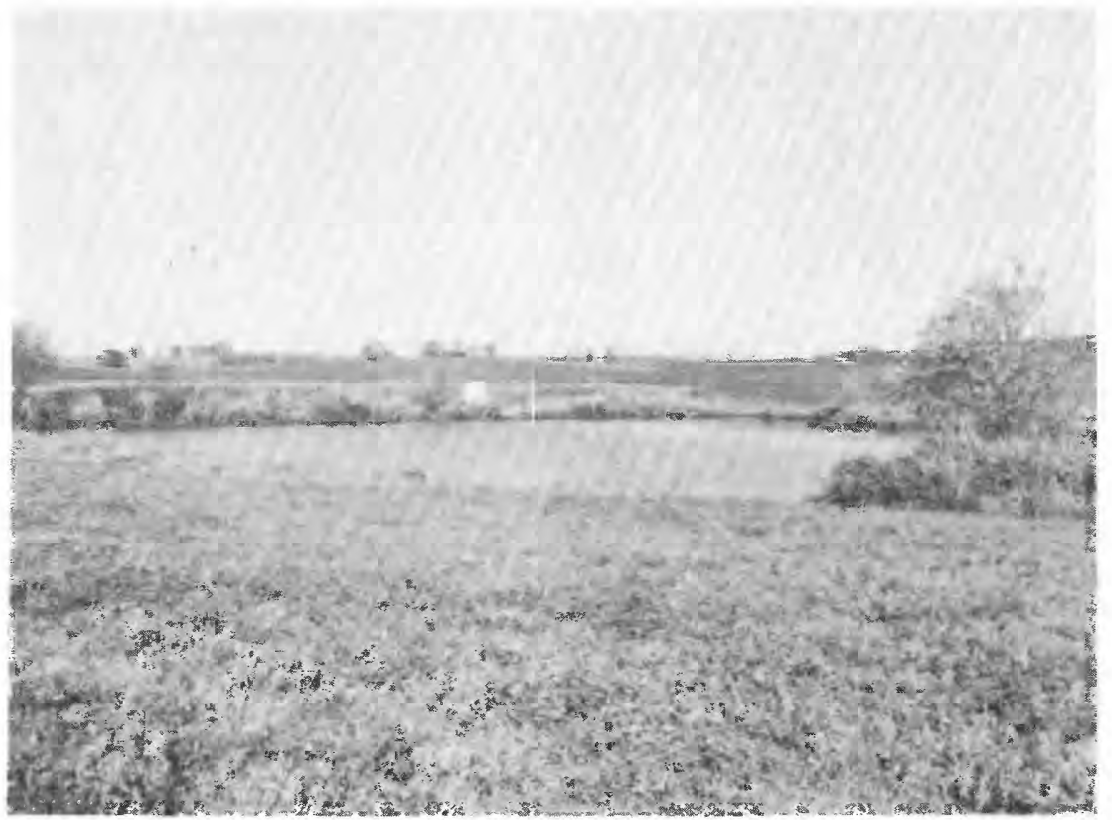

Figure 7.-Reservoir 1A (1960). 
TABLE 1.-Area and capacity of reservoir 1 from survey of March 1955

\begin{tabular}{|c|c|c|c|}
\hline $\begin{array}{l}\text { Gage height } \\
\text { (feet) }\end{array}$ & $\begin{array}{c}\text { Elevation } \\
\text { (feet above } \\
\text { mean sea level) }\end{array}$ & $\begin{array}{l}\text { Surface area } \\
\text { (acres) }\end{array}$ & $\begin{array}{l}\text { Capacity } \\
\text { (acre-feet) }\end{array}$ \\
\hline $\begin{array}{r}-11.00 \\
-10.00 \\
-9.00 \\
-8.00 \\
-7.00\end{array}$ & $\begin{array}{l}1,122 \\
1,123 \\
1,124 \\
1,125 \\
1,126\end{array}$ & & $\begin{array}{l}0.5 \\
1.0 \\
2.0 \\
3.3 \\
5.0\end{array}$ \\
\hline $\begin{array}{l}-6.00 \\
-5.00 \\
-4.00 \\
-3.00 \\
-2.00\end{array}$ & $\begin{array}{l}1,127 \\
1,128 \\
1,129 \\
1,130 \\
1,131\end{array}$ & & $\begin{array}{r}7.0 \\
9.0 \\
12.0 \\
15.0 \\
18.0\end{array}$ \\
\hline $\begin{array}{r}-1.00 \\
0.00 \\
\text { 1. } 00 \\
\text { 2. } 00 \\
\text { 3. } 00\end{array}$ & $\begin{array}{l}1,132 \\
1,133 \\
1,134 \\
1,135 \\
1,136\end{array}$ & $\begin{array}{l}\text { 3. } 32 \\
\text { 4. } 15 \\
\text { 5. } 00 \\
\text { 5. } 90 \\
\text { 6. } 85\end{array}$ & $\begin{array}{l}22.0 \\
26.0 \\
30.5 \\
35.5 \\
41.5\end{array}$ \\
\hline $\begin{array}{l}\text { 4. } 00 \\
\text { 5. } 00 \\
\text { 6. } 00 \\
\text { 7. } 00 \\
\text { 8. } 00\end{array}$ & $\begin{array}{l}1,137 \\
1,138 \\
1,139 \\
1,140 \\
1,141\end{array}$ & $\begin{array}{r}\text { 7. } 89 \\
8.90 \\
9.98 \\
11.00 \\
12.20\end{array}$ & $\begin{array}{l}\text { 48. } 1 \\
55.6 \\
64.0 \\
\text { 73. } 6 \\
\text { 84. } 4\end{array}$ \\
\hline $\begin{array}{r}9.00 \\
10.00 \\
11.00\end{array}$ & $\begin{array}{l}1,142 \\
1,143 \\
1,144\end{array}$ & $\begin{array}{l}\text { 13. } 50 \\
14.64 \\
16.00\end{array}$ & $\begin{array}{r}96.7 \\
110.3 \\
125.6\end{array}$ \\
\hline
\end{tabular}

TABLE 2.-Area and capacity of reservoir $1 A$ from survey of March 1955

\begin{tabular}{c|c|r|r}
\hline $\begin{array}{c}\text { Gage height } \\
\text { (feet) }\end{array}$ & $\begin{array}{c}\text { Elevation } \\
\text { (feet above } \\
\text { mean sea level) }\end{array}$ & $\begin{array}{c}\text { curface area } \\
\text { (acres) }\end{array}$ & $\begin{array}{c}\text { Capacity } \\
\text { (acre-feet) }\end{array}$ \\
\hline & $1,141.2$ & 0.00 & 0.00 \\
\hline 9.20 & 1,142 & .03 & .02 \\
10.00 & 1,143 & .10 & .09 \\
11.00 & 1,144 & .22 & .22 \\
12.00 & 1,145 & .28 & .41 \\
13.00 & 1,146 & .34 & .63 \\
14.00 & 1,147 & .40 & .92 \\
15.00 & 1,148 & .50 & 1.29 \\
16.00 & 1,150 & 1.03 & 2.33 \\
17.00 & 1,151 & 3.15 \\
18.00 & 1,152 & 4.25 \\
19.00 & & \\
\hline
\end{tabular}




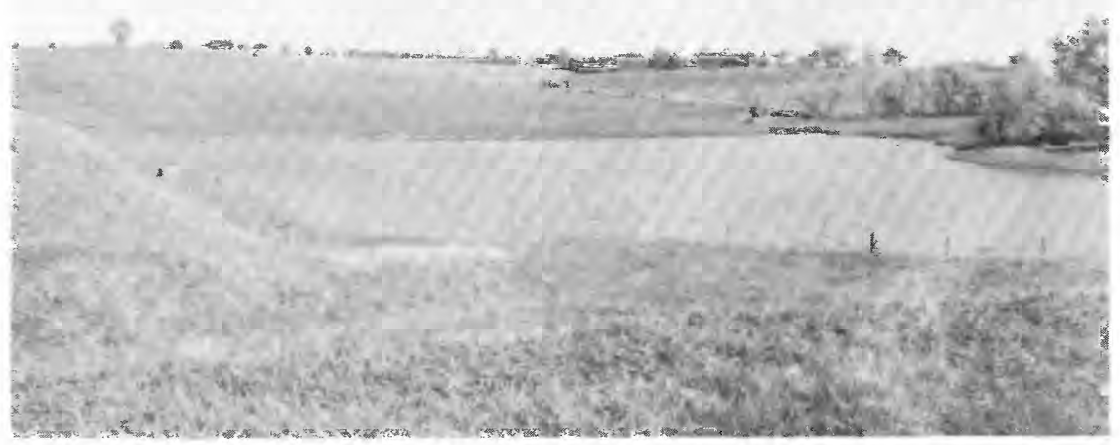

Figure 8.-Large dam about 300 feet upstream from county bridge.

Runoff from about 125 acres is detained in reservoir $1 \mathrm{~A}$ before entering reservoir 1; runoff from about 230 acres is detained in the large upstream reservoir; and runoff from about 10 acres is detained by a small stabilization structure near the northeast corner of reservoir 1. Therefore, runoff from only about 130 acres enters reservoir 1 without having first passed through an upstream structure.

Flow regulation through reservoir $1 \mathrm{~A}$ is similar to that through reservoir 1 except for the time of detention, which is much shorter because of the small reservoir capacity and the larger discharge tube. The drop-inlet structure at reservoir 1 has a concrete riser which has a rectangular opening 30 by 24 inches, and the discharge tube has a circular opening 18 inches in diameter. The drop-inlet structure at reservoir $1 \mathrm{~A}$ has a metal riser 48 inches in diameter, and the discharge tube is 36 inches in diameter. Stabilization structures 1 and 2 have earth spillways; stabilization structure 3 has a metal drop-inlet arrangement similar to that of reservoir $1 \mathrm{~A}$.

\section{RUNOFF}

Comprehensive analysis of runoff data on the subwatershed is not possible for several reasons: no storage nor discharge data were obtained at three small upstream reservoirs during $1955-59$ nor at a large upstream reservoir that was completed in May 1959; complete data are available only for discharge from reservoirs 1 and $1 \mathrm{~A}$ and are not available for changes in reservoir content throughout the range

214-649 O-66- - 3 
of reservoir stage during 1955-59. Although complete runoff data are not available, total runoff in the subwatershed can be approximated. Table 3 shows reservoir discharge and other pertinent hydrologic data for 1955-59. The data on evaporation and seepage were estimated; the data on direct precipitation on the reservoirs were based on data obtained at the precipitation gages in other parts of the subwatershed. Only 0.4 percent of the 125-acre drainage area of reservoir $1 \mathrm{~A}$ was open water surface; for the remaining 370 acres of the subwatershed, 1.5 percent was open water surface during 195558 and 2.8 percent since 1959 . Thus, estimated evaporation, seepage, and direct precipitation on reservoir surfaces were proportionately much lower for reservoir $1 \mathrm{~A}$ than for the rest of the subwatershed.

The data in table 3 indicate that the average annual runoff for the entire Brownell Creek subwatershed was 3.3 inches during 1955-59 and that runoff was somewhat lower from the drainage area of reservoir $1 \mathrm{~A}$ than from the rest of the subwatershed.

Brownell Creek subwatershed is in the Little Nemaha River basin. Discharge data show that the average annual runoff for the drainage area (218 sq miles) of Little Nemaha River near Syracuse was about 3.8 inches during $1955-59$.

Between December 27, 1959, and about March 15, 1960, exceptionally heavy snowfalls occurred in southeastern Nebraska. On March 21, 1960, a detailed snow survey was made in Brownell Creek subwatershed. For this area of less than 1 square mile, over 500 observations of snow depth and about 20 moisture-content determinations were made. Random observations indicated that the ground was frozen in most of the watershed, but the depth of frost was not determined. Melting was insignificant between March 21 and March 26; a reconnaissance of the area on March 26 indicated no change in snow depth from that measured on March 21. The snow over the subwatershed averaged 1.03 feet in depth and was rather uniformly distributed. Moisture content of the snow averaged 3.49 inches of water in each foot of snow; this exceptionally high moisture content was caused by considerable melting and compaction between about February 25 and March 26. Moisture-content determinations of the snow cover in Lincoln, Nebr., on March 22 indicated 3.60 inches of water in each foot of snow.

On March 27, 1960, the snow began to melt very rapidly and by the evening of March 28, an estimated 95 percent or more of the snow cover in the subwatershed had melted. At the time the melting began, all reservoirs were at maximum dead-storage capacity; therefore, reservoir outflow was equal to inflow, and none of the runoff resulted in additional reservoir storage. Runoff, as indicated by the discharge from reservoir 1 during March $27-31$, was the result of snowmelt. 
TABLE 3.-Reservoir discharge and other hydrologic data, reservoirs 1 and $1 \mathrm{~A}$

\begin{tabular}{|c|c|c|c|}
\hline & Reservoir 1A & Reservoir 1-1A & Reservoir 1 \\
\hline Area $_{\ldots}$ & 125 & 370 & 495 \\
\hline \multicolumn{4}{|c|}{ Reservoir discharge, in acre-feet } \\
\hline $\begin{array}{l}1955^{1} \\
1956 \\
1957 \\
1958\end{array}$ & $\begin{array}{l}22 \\
11 \\
7.8 \\
57 \\
36\end{array}$ & $\begin{array}{r}83 \\
38 \\
19 \\
146 \\
2187\end{array}$ & $\begin{array}{r}105 \\
49 \\
27 \\
203 \\
2223\end{array}$ \\
\hline $1955-59$ & ${ }^{3} 134$ & 473 & 607 \\
\hline \multicolumn{4}{|c|}{ Reservoir discharge, in percentage of total } \\
\hline $\begin{array}{l}1955 \\
1956 \\
1958 \\
1959\end{array}$ & $\begin{array}{l}21 \\
22 \\
29 \\
28 \\
16 \\
22\end{array}$ & $\begin{array}{l}79 \\
78 \\
71 \\
72 \\
84 \\
78\end{array}$ & $\begin{array}{l}100 \\
100 \\
100 \\
100 \\
100 \\
100\end{array}$ \\
\hline
\end{tabular}

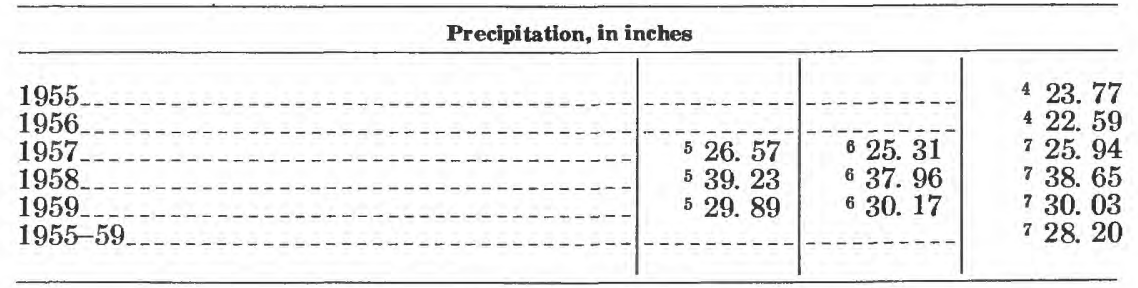

\begin{tabular}{l}
\hline \multicolumn{3}{c}{ Reservoir evaporation, ${ }^{8}$ in acre-feet } \\
\hline 1955 \\
1956
\end{tabular}

1955-59 Miscellaneous data

Direct precipitation on surface of reservoir _...................... acre-feet. Estimated seepage loss...... Total runoff__. Average annual runoff........... inches. \begin{tabular}{r|r|r} 
& & \\
6 & 72 & 78 \\
5 & 35 & 40 \\
8142 & 10541 & 683 \\
2.7 & 3.5 & 3.3
\end{tabular}

1 Includes new storage in reservoir 1 and estimated discharge from reservoir $1 \mathrm{~A}$ for October 1954 to $\mathrm{March}$ 1955.

${ }^{2}$ Includes 15 acre-feet of new storage.

3 Total rounded.

4 At Syracuse.

64 miles northeast of Syracuse.

63 miles north-northeast of Syracuse.

7 A verage.

8 Based on pan-evaporation data at Lincoln and on information from Kohler, Nordenson, and Baker (1959).

Total runof $=$ reservoir $1 \mathrm{~A}$ inflow+direct precipitation on reservoir $1 \mathrm{~A}=$ reservoir $1 \mathrm{~A}$ outflow +evaporation+seepage.

10 Total runoff =reservoir 1 inflow+direct precipitation on reservoir $1=$ reservoir 1 outflow+evaporation +seepage+storage-reservoir $1 \mathrm{~A}$ outflow. 
Computations based on average snow depth and average moisture content indicate that 148 acre-feet of water was contained in the accumulated snow. The discharge from reservoir 1 during March 2731 was about 115 acre-feet and represents about 78 percent of the water incorporated in the snow cover in the subwatershed (see table 4); 33 acre-feet of the water in the snow apparently did not enter the reservoirs. Most of this unaccounted for water probably infiltrated the soil in areas where ground frost was absent or where the upper part of the soil profile was not frozen, or it infiltrated the soil after temporary terrace storage. Some of the melt water may have recharged the ground-water reservoir, and minor amounts may have been lost through sublimation from the snow surface and through evaporation from the reservoirs.

TABLE 4.-Hydrologic data, Brownell Creek subwatershed No. 1 Mar. 27-31, 1960

\begin{tabular}{|c|c|c|c|c|c|c|}
\hline & \multicolumn{2}{|c|}{ Drainage area } & \multirow{2}{*}{$\begin{array}{l}\text { Water in } \\
\text { snow cover } \\
\text { (acre-feet) }\end{array}$} & \multicolumn{2}{|c|}{ Discharge } & \multirow{2}{*}{$\begin{array}{l}\text { Runoff, } \\
\text { percentage } \\
\text { from } \\
\text { snowmelt }\end{array}$} \\
\hline & Acres & $\begin{array}{c}\text { Percentage } \\
\text { of total }\end{array}$ & & Acre-feet & $\begin{array}{l}\text { Percentage } \\
\text { of total }\end{array}$ & \\
\hline Reservoir $1 \mathrm{~A}_{1-1 \mathrm{~A}}$ & $\begin{array}{l}125 \\
370 \\
495\end{array}$ & $\begin{array}{r}25 \\
75 \\
100\end{array}$ & $\begin{array}{r}37 \\
111 \\
148\end{array}$ & $\begin{array}{r}20 \\
95 \\
115\end{array}$ & $\begin{array}{r}17 \\
83 \\
100\end{array}$ & $\begin{array}{l}54 \\
86 \\
78\end{array}$ \\
\hline
\end{tabular}

\section{METHOD OF INVESTIGATIONS}

From April 1, 1955, to September 30, 1959, suspended sediment was sampled at 14 locations in Brownell Creek subwatershed. (See fig. 1.) Outflow from reservoirs 1 and $1 \mathrm{~A}$ was sampled at locations $1-\mathrm{D}$, $1-\mathrm{U}$, and 2 ; upstream from these reservoirs, flow was sampled at locations 3-13. Locations 10-13 were not used before June 30, 1956.

Outflow was sampled from reservoir $1 \mathrm{~A}$ at the discharge tube (fig. 9 ) and from reservoir 1 at the discharge tube (fig. 10) and at the trash rack that protects the inlet of the discharge tube. Samples were collected at the discharge tubes with a U.S. DH-48 sampler and at the trash rack with automatic suspended-sediment samplers in vertical stacks on the upstream corners of the rack (fig. 11). At reservoir 1 , samples were also collected at the discharge tube by a continuous suspended-sediment sampler having the intake nozzle in a fixed position inside the discharge tube.

Inflow to the reservoirs was sampled with a U.S. DH-48 sampler or with a handline sampler at locations $4-13$ and with automatic suspended-sediment samplers at locations $3,6-8,10$, and 13 . The automatic samplers were placed in the channels so that the initial samples were collected when the flow reached a depth of about 0.7 foot. Automatic samplers were arranged in vertical stacks so that 
successive samples were obtained as the stage increased. Manual sampling at locations 5 and 9 was done by a local resident, who was assisted by Geological Survey personnel during periods of major runoff.

Reservoir stage recorders are on the upstream side of the dams at reservoirs 1 and 1A. (See figs. 6, 7.) Water discharge measurements are made about 100 feet downstream from the discharge tubes of the reservoirs.

The suspended-sediment concentrations of all samples, in parts per million by weight, were determined in the laboratory. The particlesize distribution of the suspended sediment in selected samples was determined by standard methods based on the fall velocity of the particles. The particle-size distribution of the sand from samples of deposited sediment was determined by the sieve method; the particle-size distribution of the silt and clay was determined by sedimentation methods.

For days of significant discharge, the suspended-sediment concentrations were plotted on the gage-height chart, and a smooth curve was drawn through the plotted points; the mean daily concentration was determined from this curve. Daily suspended-sediment discharge, in tons, was computed by multiplying daily mean concentration by

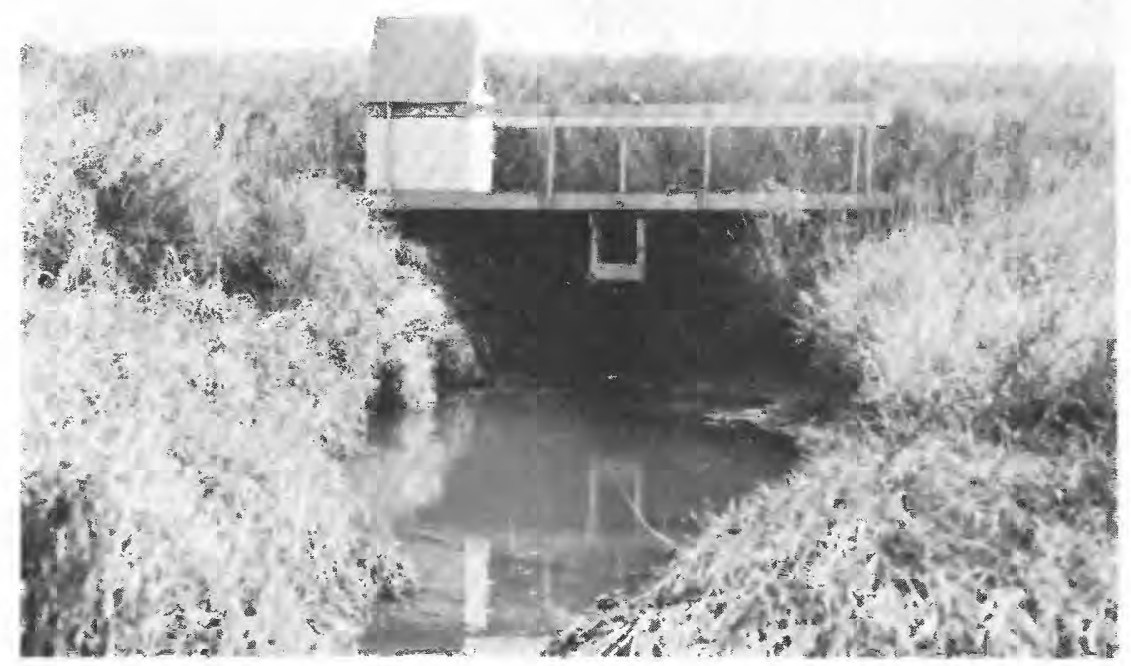

Figure 9.-Discharge tube, reservoir $1 \mathrm{~A}$. 
daily mean water discharge and by a constant. On days when both concentration and water discharge were changing rapidly, each day was divided; sediment discharge that had been computed separately for parts of the day were totaled for the daily discharge.

\section{SUSPENDED SEDIMENT}

\section{SUSPENDED-SEDIMENT DISCHARGE}

The periods of significant outflow from reservoir 1 between April 1955 and September 1959 are summarized in table 5. The sediment discharge and water discharge shown for these periods represent about 99 and 88 percent, respectively, of the total from April 1955 to September 1959 ; a few very small sediment discharges are not included. The weighted suspended-sediment concentrations are the concentrations that would result if all the water and all the sediment discharged during a given period were uniformly mixed. For the periods shown in this table (99 percent of the sediment discharge and 88 percent of the water discharge), the weighted concentration is 587 parts per million. If the remaining 12 percent of the water

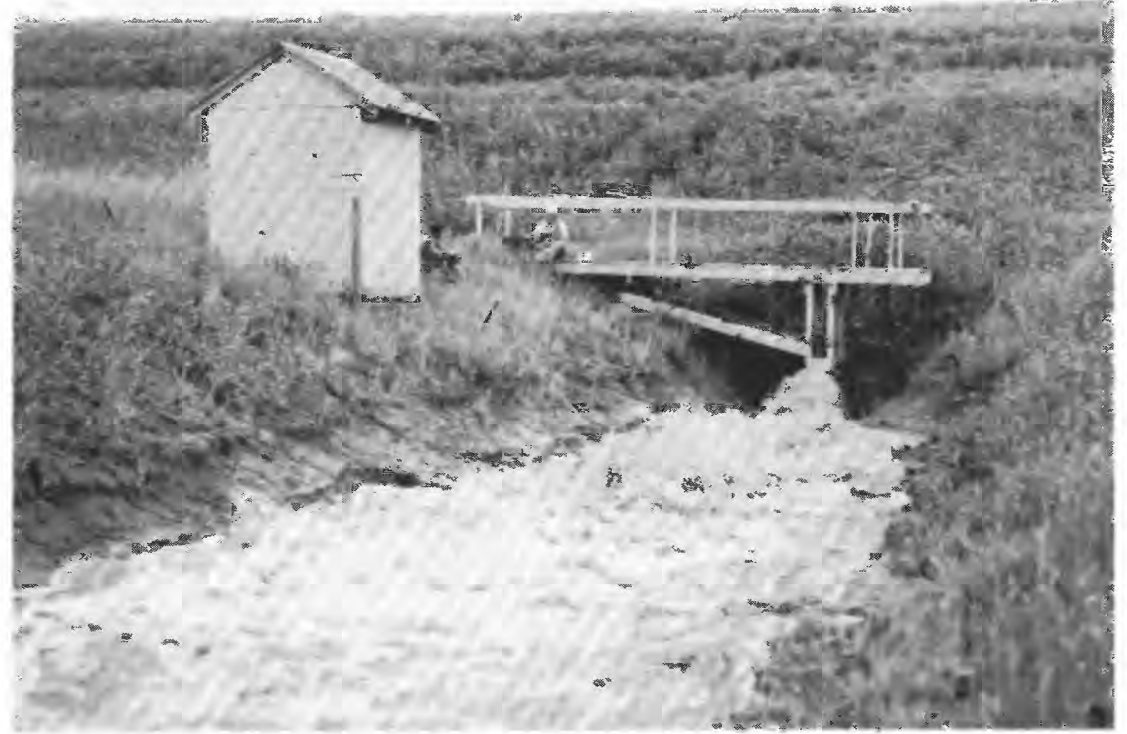

Figure 10.-Outflow from discharge tube, reservoir 1 (June 24, 1955, water discharge about 32 cfs). 


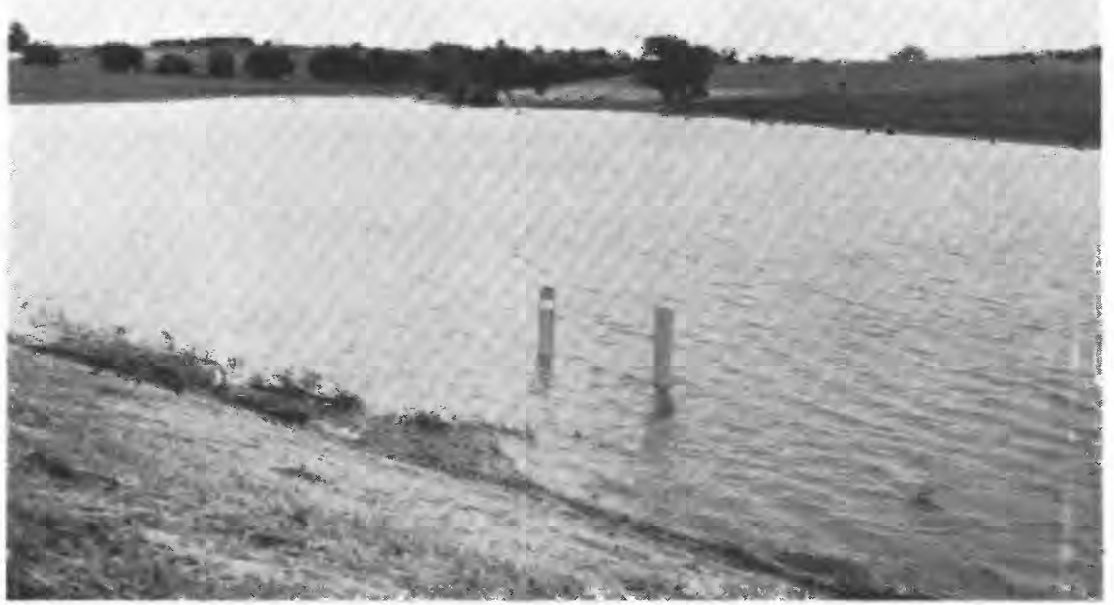

FIGURE 11.-Partly submerged vertical stack of automatic suspended-sediment samplers at trash rack, reservoir 1 (June 24, 1955, reservoir elevation about 1,140 ft).

discharge, which had a weighted concentration of only $24 \mathrm{ppm}$, is included, the weighted concentration for all the water discharged from the reservoir between April 1955 and September 1959 would be $525 \mathrm{ppm}$.

The periods of significant outflow from reservoir 1A during 195559 are summarized in table 6 . Because the drainage area is small in size, has flash-type runoff characteristics and a short detention time, the data for reservoir $1 \mathrm{~A}$ are probably much less reliable than those for reservoir 1.

Sediment discharge from reservoir 1 as a result of the storm of June 23-24, 1955, was greater than that during any other single period from 1955 to 1959 , inclusive, and represents about one-third of the total sediment discharge from reservoir 1 during 1955-59. Hydrologic information for reservoirs 1 and $1 \mathrm{~A}$ is shown in figures 12 and 13. Samples at location 3 indicate that the peak suspended-sediment concentration for inflow occurred during the initial sharp rise in stage. During a 12-hour period on June 23-24, 4.30 inches of rain fell at a maximum intensity of about 2.00 inches per hour. At reservoir 1, peak inflow, based on preliminary data, was about $700 \mathrm{cfs}$; peak out- 
TABLE 5.-Summary of outflow from reservoir 1, 1955-59

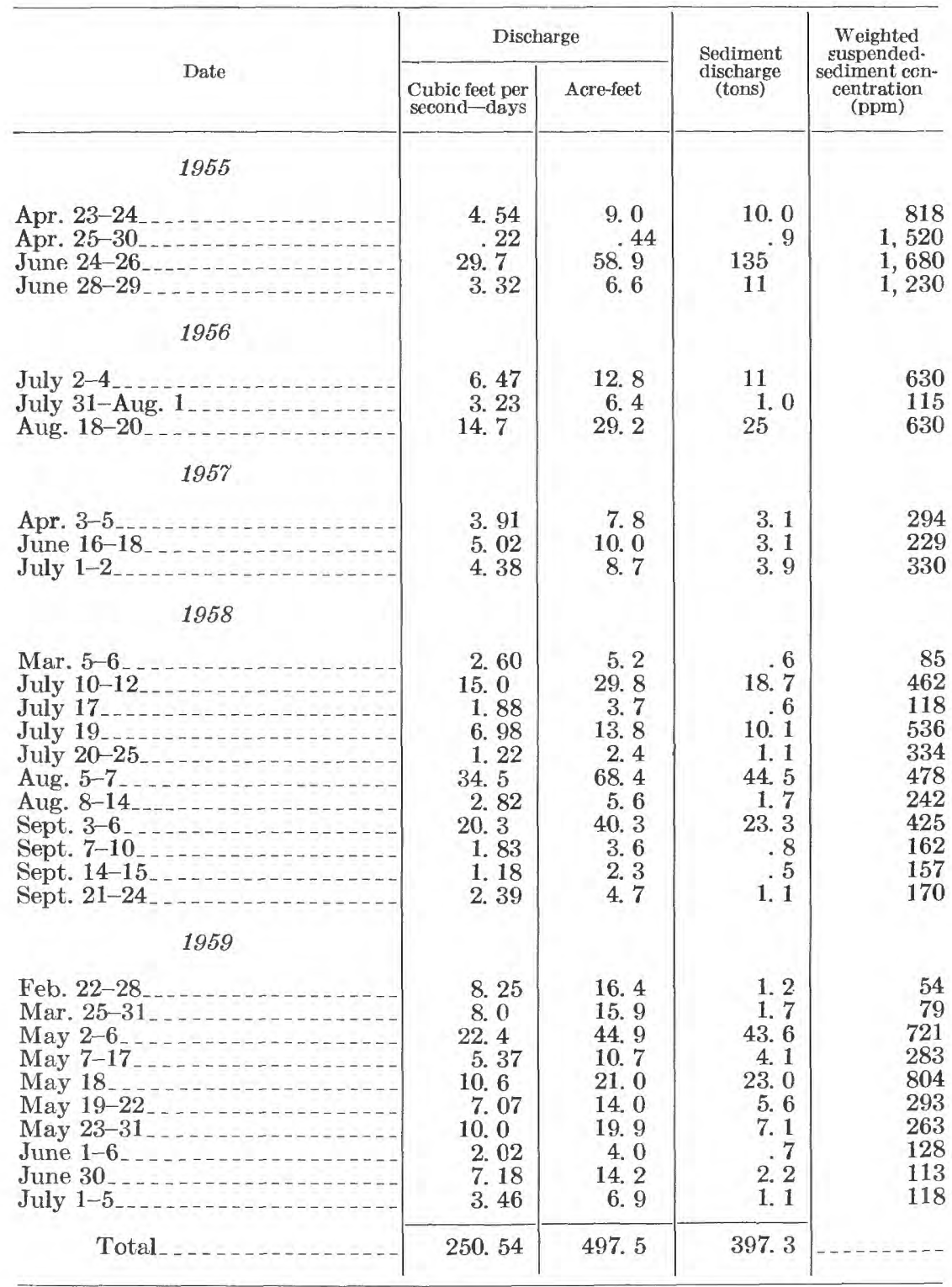

flow was 32.8 cfs; peak suspended-sediment concentration of outflow was $3,400 \mathrm{ppm}$; maximum instantaneous sediment discharge was 275 tons per day; and total sediment discharge was 135 tons. The peak inflow of about $700 \mathrm{cfs}$, or about $905 \mathrm{cfs}$ per square mile, is indicative of the intensity of the precipitation and runoff during this storm. 
The peak inflow probably would have exceeded $700 \mathrm{cfs}$ if the upstream control structures had not been present. Figure 14 is an aerial view of the reservoirs and part of the subwatershed on June 24, 1955.

Summaries of other selected periods of major discharge from reservoir 1 are shown in figures $15-20$.

About 77 percent of the total sediment discharge from reservoir 1 during 1955-59 occurred during seven outflow periods, each of which was less than 5 days in duration. About 88 percent of the total sediment discharge was during 11 outflow periods that had a combined duration of 30 days.

TABLE 6.-Summary of outflow from reservoir $1 A, 1955-59$

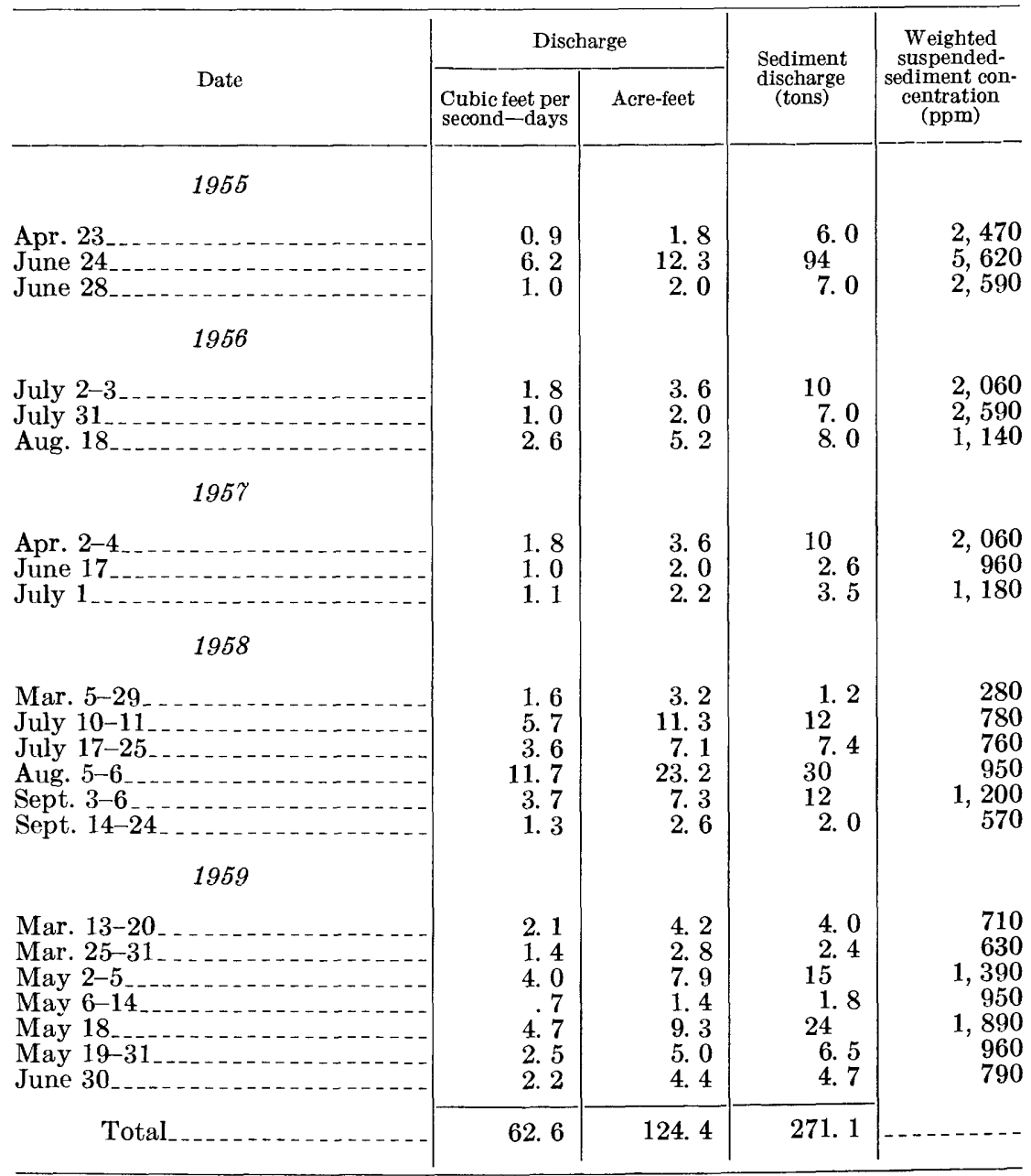




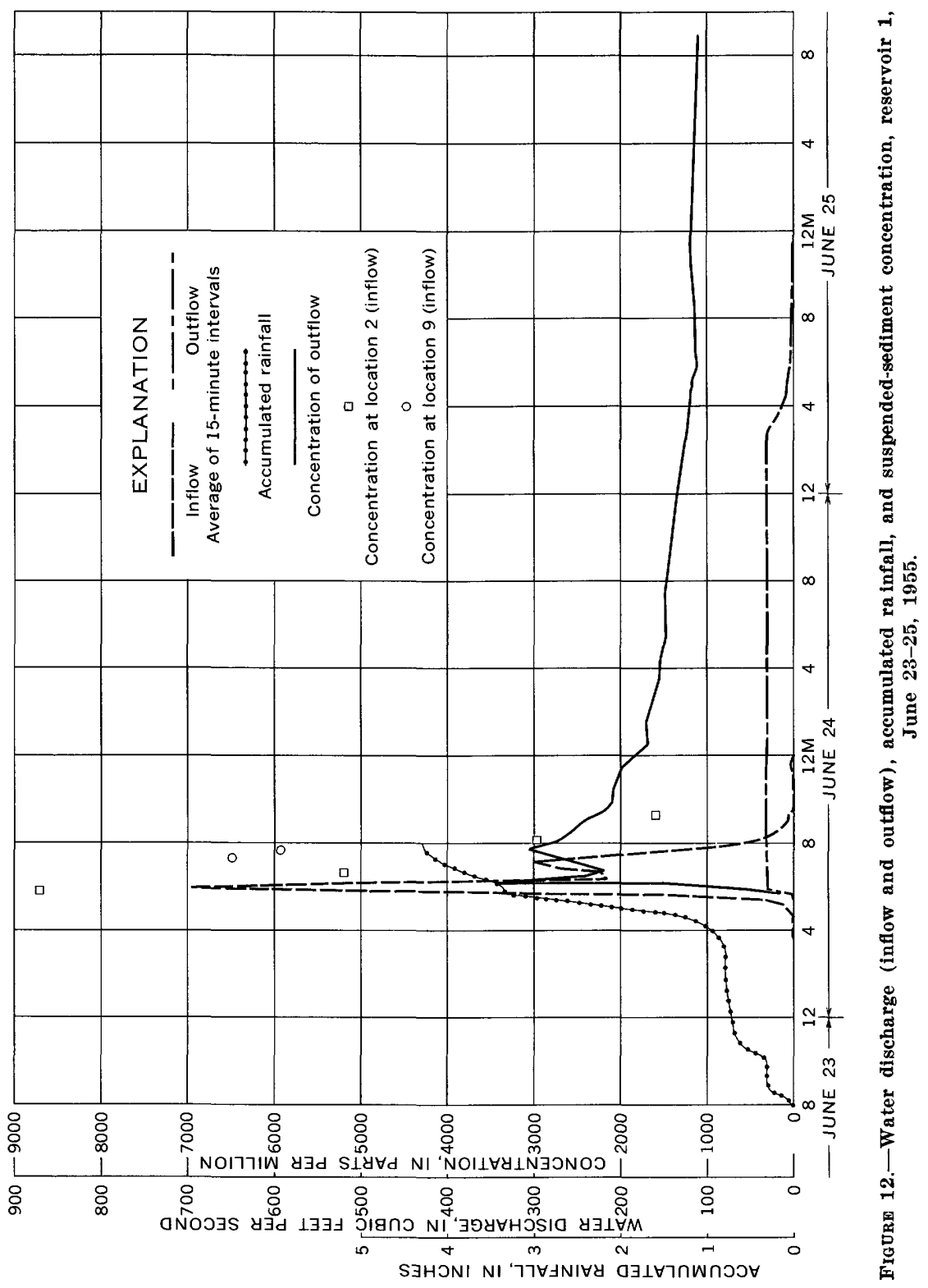




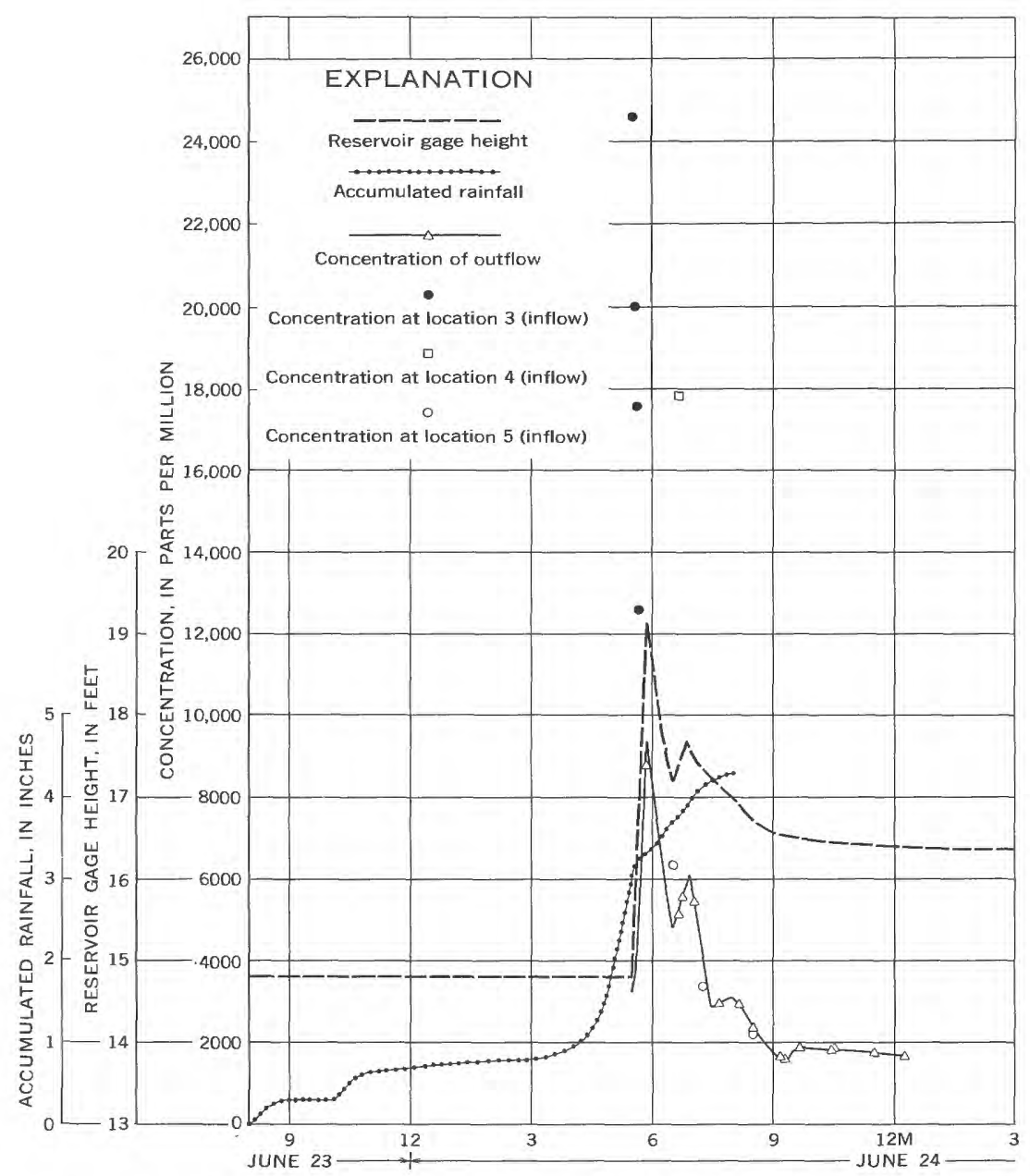

Figure 13.-Reservoir gage height, accumulated rainfall, and suspended-sediment concentration, reservoir 1A, June 23-24, 1955. 


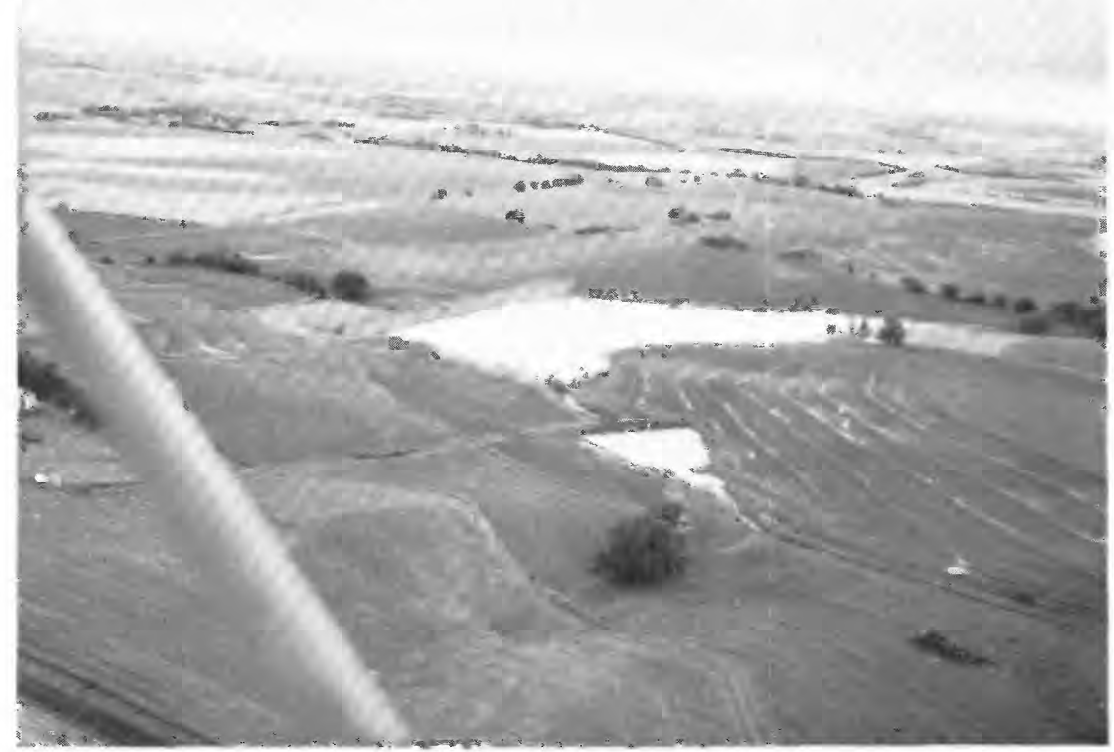

Figure 14.-Downstream view of part of Brownell Creek subwatershed, June 24, 1955 Photograph by Soil Conservation Service.

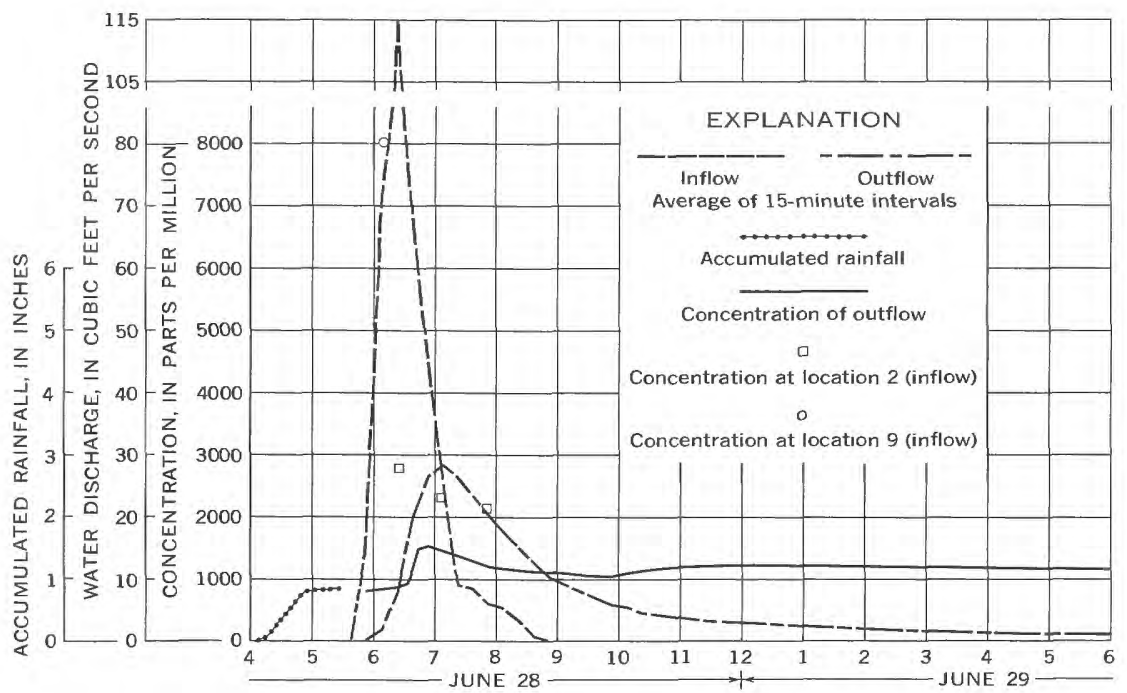

Frgure 15.-Water discharge (inflow and outflow), accumulated rainfall, and suspendedsediment concentration, reservoir 1, June 28-29, 1955. 


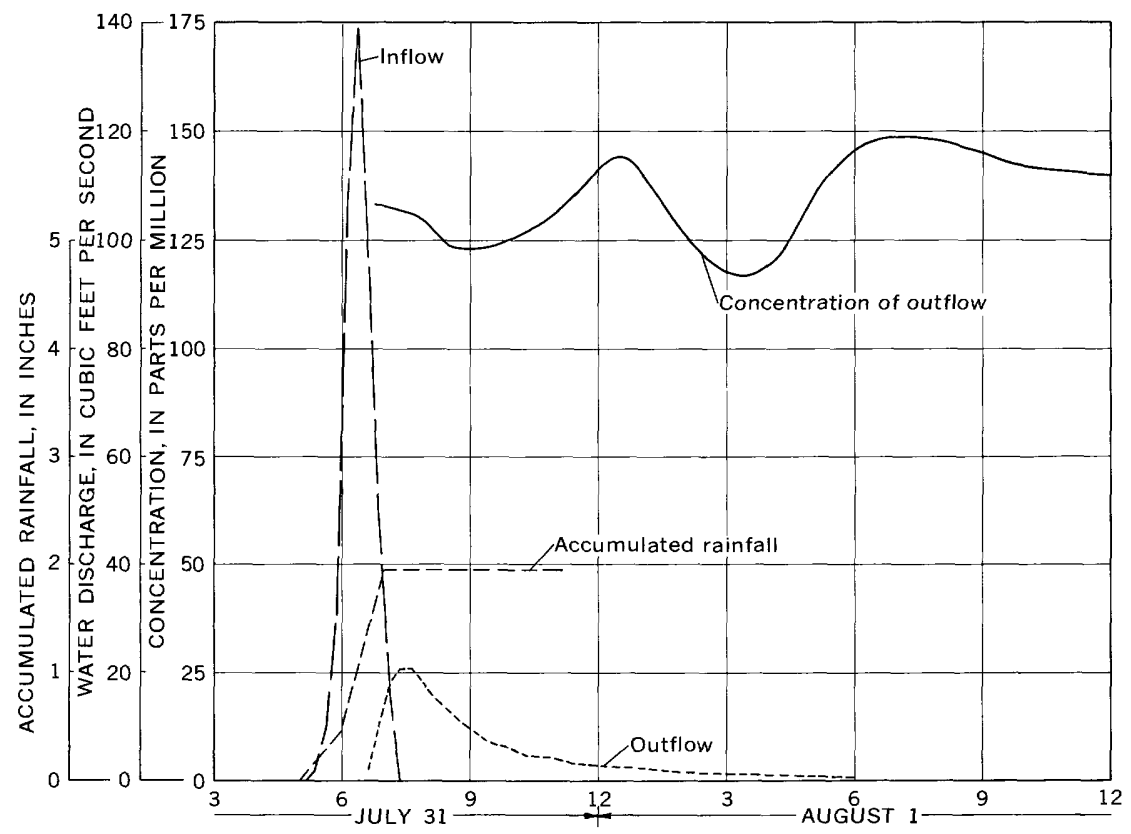

FigdRe 16.- Water discharge (inflow and outflow), accumulated rainfall, and suspendedsediment concentration, reservoir 1, July 31-Aug. 1, 1956.

The large upstream reservoir, which was completed in 1959, retains much of the sediment derived from the eastern part of the subwatershed and reduces significantly the sediment discharge into reservoir 1. The sediment discharge from both the upstream reservoir and reservoir $1 \mathrm{~A}$ is predominantly clay; therefore runoff from about 70 percent of the subwatershed transports mainly clay into reservoir 1. Although some of this clay is undoubtedly deposited in reservoir 1, a large part remains in suspension and is discharged from the reservoir. Since May 1959, a disproportionately large percentage of the sediment deposited in reservoir 1 is derived from the northwestern part of the subwatershed because the runoff flows directly into reservoir 1 without first passing through the other reservoirs.

Field observations and data on inflow and outflow concentrations indicate that an inflow of high suspended-sediment concentration may behave as a density (turbidity) current upon entering the reservoir. The relation of outflow concentration to inflow concentration for a given runoff period varies with such factors as the intensity and duration of runoff, reservoir stage at the beginning of the runoff period, maximum reservoir stage during the runoff period, antecedent inflow conditions, and water temperature of inflow and reservoir water.

Suspended-sediment discharge cannot be computed for the different 
inflow sampling sites; however, the instantaneous suspended-sediment discharge into the reservoir at selected times can be computed from partly estimated data. On June 24, 1955, the maximum instantaneous suspended-sediment discharge into the reservoir was probably about 35,000 tons per day; this discharge probably prevailed for only a few minutes. Maximum discharges of 10,000-25,000 tons per clay probably occurred for periods of a few minutes in 1956,1958 , and 1959. The data indicate that maximum inflow concentration and suspended-sediment discharge either precede or coincide with maximum water discharge.

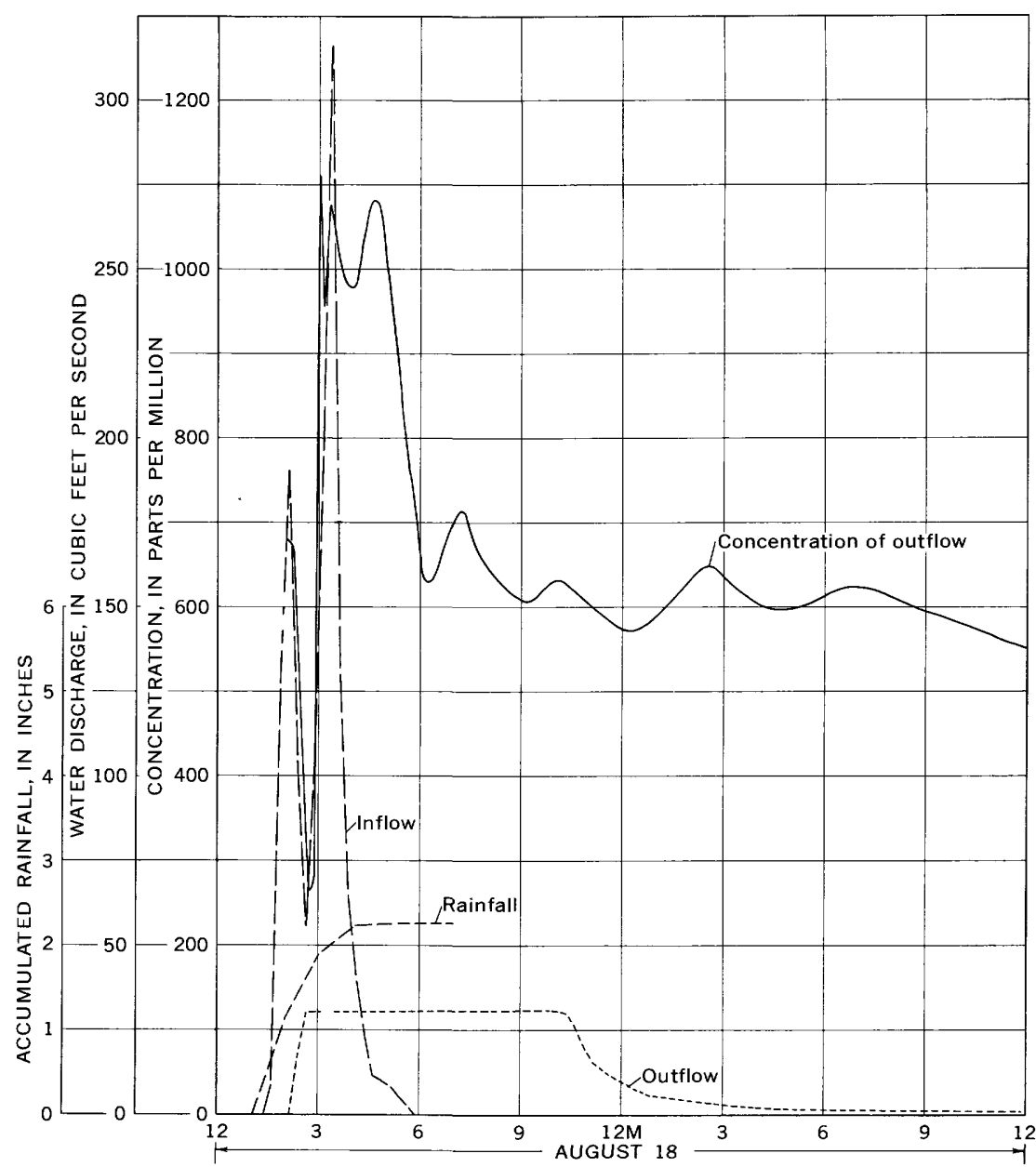

Figure 17.-Water discharge (inflow and outflow), accumulated rainfall, and suspendedsediment concentration, reservoir 1, Aug. 18, 1956. 


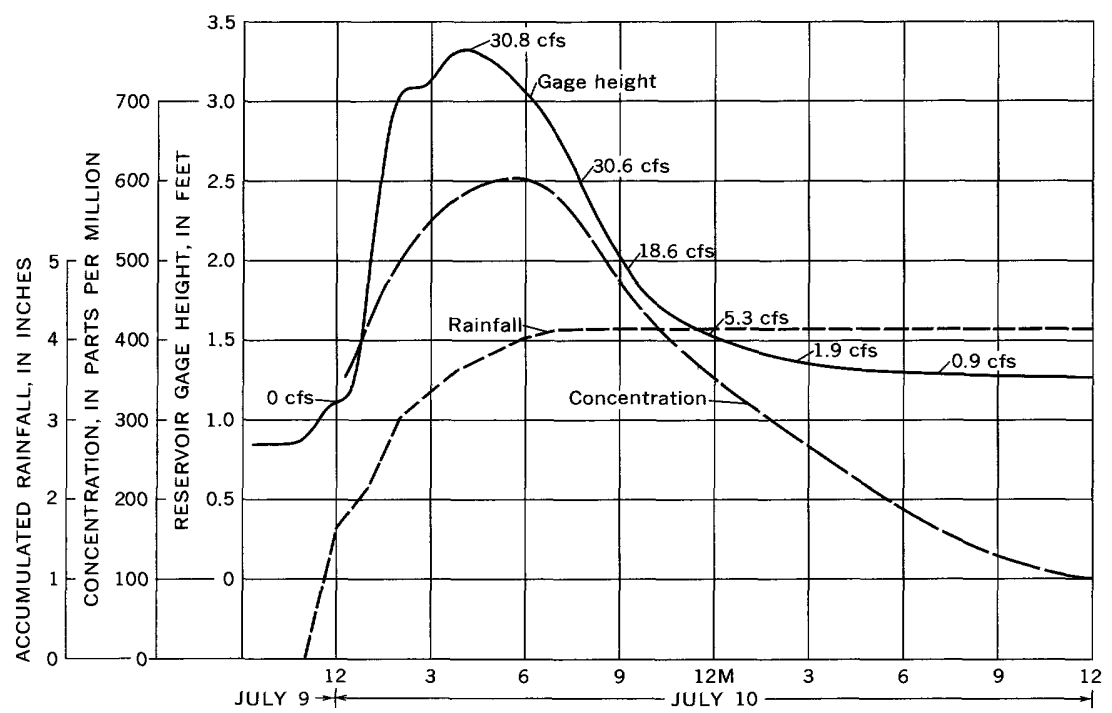

Figdre 18.-Gage height, accumulated rainfall, suspended-sediment concentration, and water discharge, reservoir 1, July 9-10, 1958.

\section{PARTICLE-SIZE OF SUSPENDED SEDIMENT}

Particle-size distribution of suspended-sediment samples (shown graphically in figure 21,) indicates that the outflow (tables 7,8) has a higher percentage of clay than the inflow (tables 9, 10), that most of the sand entering reservoir $1 \mathrm{~A}$ is trapped, and that all the sand and much of the silt and clay entering reservoir 1 are trapped.

Figure 22 shows that the percentage of clay is related to the suspended-sediment concentration of inflow to reservoirs 1 and $1 \mathrm{~A}$. Although the plotted points show considerable scatter, the curve indicates a general tendency for the percentage of clay to decrease as suspended-sediment concentration increases. The concentration of clay generally increases, however, as the total suspended-sediment concentration increases.

For selected inflow and outflow samples, particle-size distribution of the silt-clay fraction was determined by two different settling mediums-distilled water having a dispersing agent added and native water. (See tables 7-10.) Such data on size distribution may indicate roughly the degree and extent of flocculation and deposition in a reservoir; however, a considerable part of the clay shown for the dispersed analysis may have been transported into the reservoir as siltor sand-size soil aggregates, and preparation of the sample for analysis under dispersed conditions destroys these aggregates. Differences between size distribution in the two different mediums may be caused as much by destruction of original soil aggregates as by the flocculating ability of the native water. 


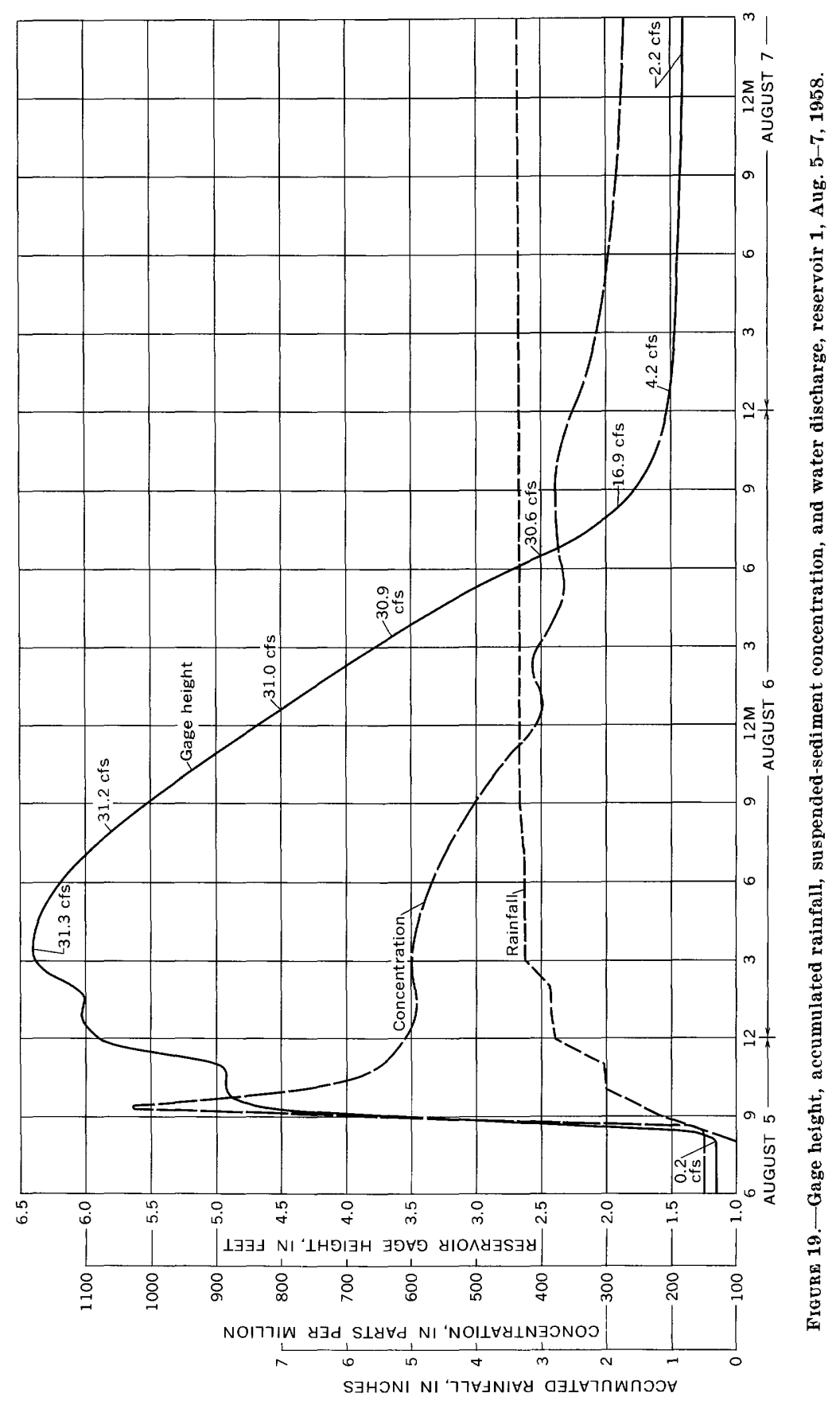




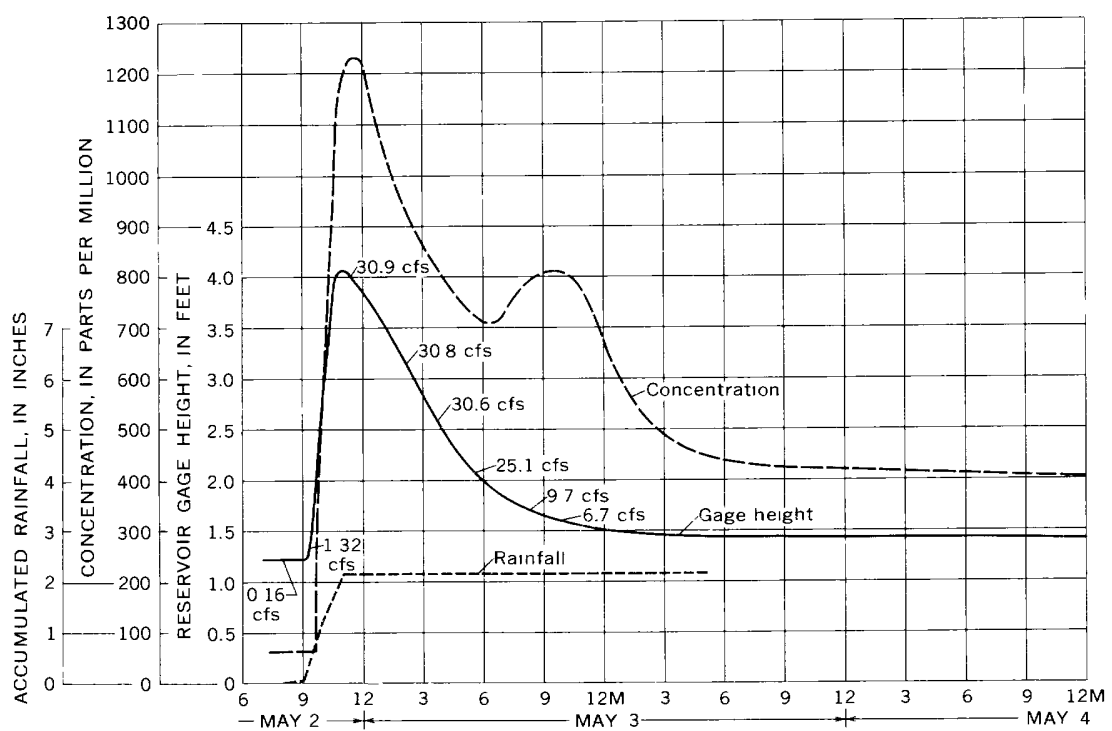

Figure 20.-Gage height, accumulated rainfall, suspended-sediment concentration, and water discharge, reservoir 1, May 2-4, 1959.

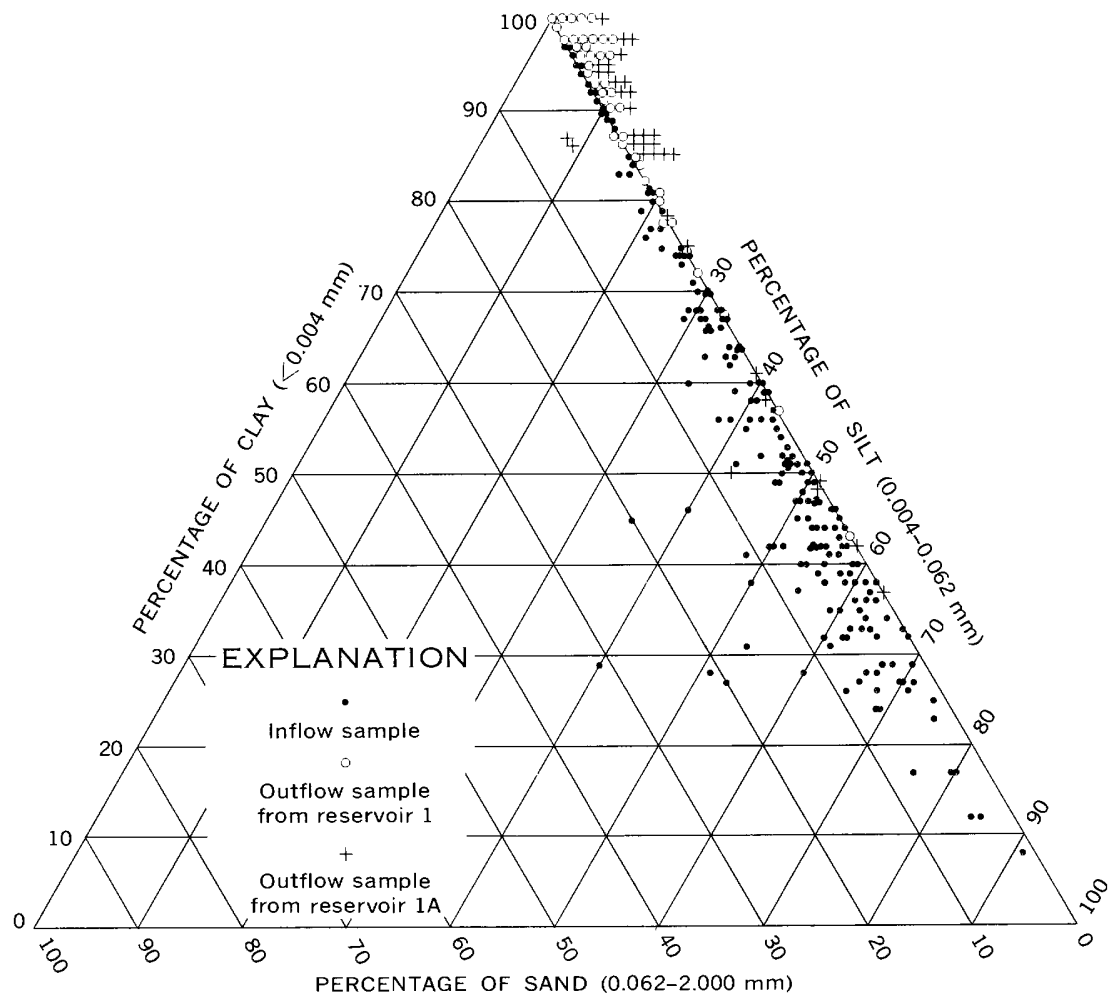

FIGURE 21.-Percentage of clay, silt, and sand in samples from Brownell Creek subwatershed. 


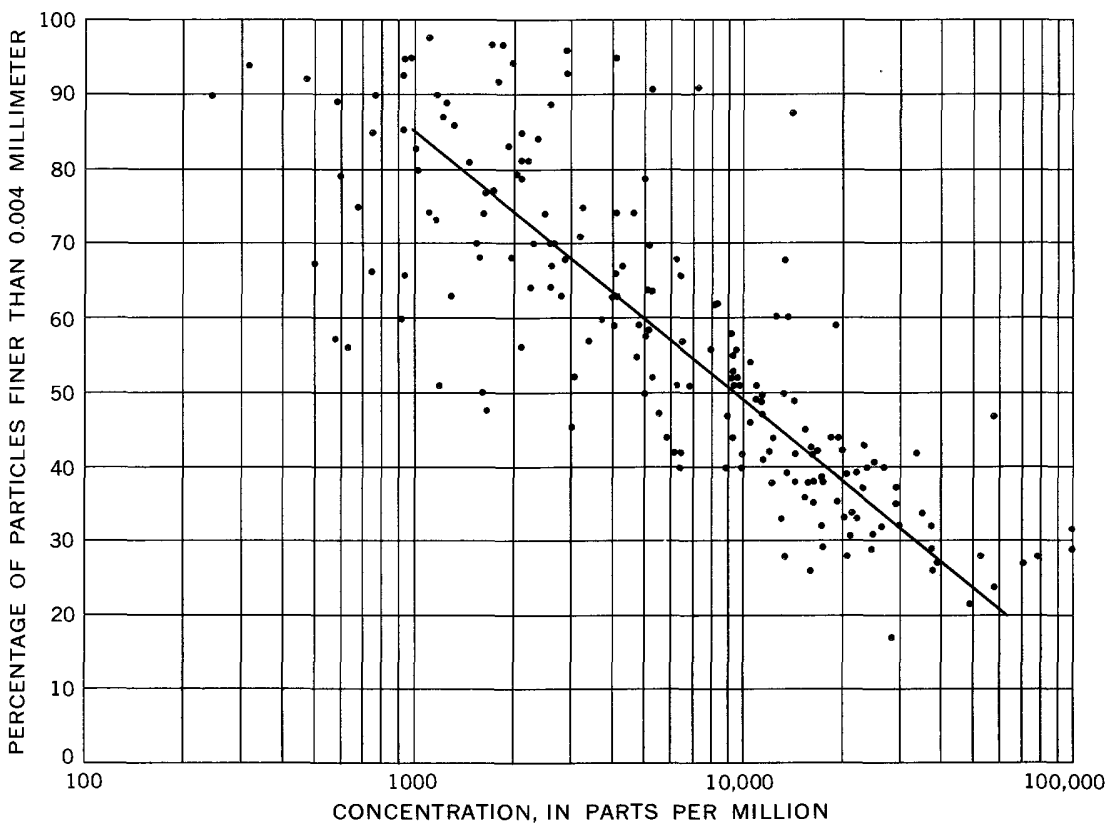

FigURE 22.-Relation of percentage of clay to suspended-sediment concentration, inflow to reservoirs 1 and $1 \mathrm{~A}$.

\section{DEPOSITED SEDIMENT}

The trap efficiency of reservoir 1 eventually will be computed using data from reservoir surveys and data on sediment discharge from the reservoir. At present (1961), the results of the surveys are not available and the amount of sediment deposition in the reservoir is not known. Deposition in reservoir 1 can be computed, however, from the available data on concentration and particle-size distribution of inflow from different parts of the subwatershed, on sediment discharge from reservoirs 1 and $1 \mathrm{~A}$, data on estimates of runoff distribution within the subwatershed, and from a small amount of data on bulk density of reservoir deposits. About 4.5 acre-feet of sediment is estimated to have been deposited in reservoir 1 and in backwater reaches of channels leading into this reservoir. Trap efficiency of reservoir 1 is estimated to have been between 90 and 95 percent during 195559 , but the trap efficiency (computed as the ratio, expressed as a percentage, of the weight of sediment retained in the reservoir to the weight of sediment entering the reservoir) has probably decreased since the completion of the large upstream reservoir in 1959. Much less sediment probably enters reservoir 1 , and of the sediment that does enter, the percentage of clay is probably higher than it was before construction of the upstream reservoir. Most of the sediment 
that is discharged from the upstream reservoir is clay, and much of this clay probably remains in suspension and is discharged from reservoir 1. The decrease in sediment inflow to reservoir 1 is probably greater than the decrease in sediment discharge from reservoir 1 , and the result should be an apparent decrease in trap efficiency of reservoir 1; however, the upstream reservoir probably has a trap efficiency similar to that of reservoir 1 , and the actual decrease in trap efficiency of reservoir 1 will, no doubt, be slight. The rate of sediment accumulation in reservoir 1 has probably decreased markedly since about May 1959.

Reservoir bottom samples from eight locations in reservoir 1 and from three locations in reservoir $1 \mathrm{~A}$ (fig. 23) were obtained and analyzed by the Agricultural Research Service during the spring of 1958. For reservoir 1, the average bulk density of the samples, expressed as grams per cubic centimeter, was 1.16; for reservoir 1A, the average bulk density of the three samples was 0.89 . For reservoir 1 , the bulk density generally increased with depth and averaged 1.06 for about the upper 4 inches of sediment deposited, 1.19 for the material about $4-8$ inches below the surface of the deposit, and 1.25 for the material more than 8 inches below the surface. For the samples collected at reservoir $1 \mathrm{~A}$, bulk density was not related to depth. (See table 11.)

The correlation between particle-size distribution of deposited material and bulk density is only fair. However, the sample having the highest percentage of sand had the highest bulk density (reservoir 1), and the sample having the highest percentage of clay had the second lowest bulk density (reservoir 1A). Figure 24 shows the relation between percentage of sand and bulk density.

For reservoir 1, the percentage of sand ranged from 9 to 43 , and the percentage of clay ranged from 23 to 40 ; for reservoir $1 \mathrm{~A}$, the percentage of sand ranged from 8 to 20 , and the percentage of clay from 27 to 46 . The particle-size classification used for this series of samples is that followed by the U.S. Department of Agriculture: sand, 0.05 to $2.0 \mathrm{~mm}$; silt, 0.002 to $0.05 \mathrm{~mm}$; clay, less than $0.002 \mathrm{~mm}$. Particle-size analyses were made on about half the samples obtained and the results are given in table 11.

In February 1957, samples of deposited sediment were collected between the northeast corner of the reservoir and the junction of the two main channels that drain the northern two-thirds of the subwatershed. Figure 23 shows the location of the sampling sections, and table 12 shows the particle-size distribution of the sampled material. In the reach from the downstream edge of the delta to the termination of channel backwater, the particle-size distribution of 


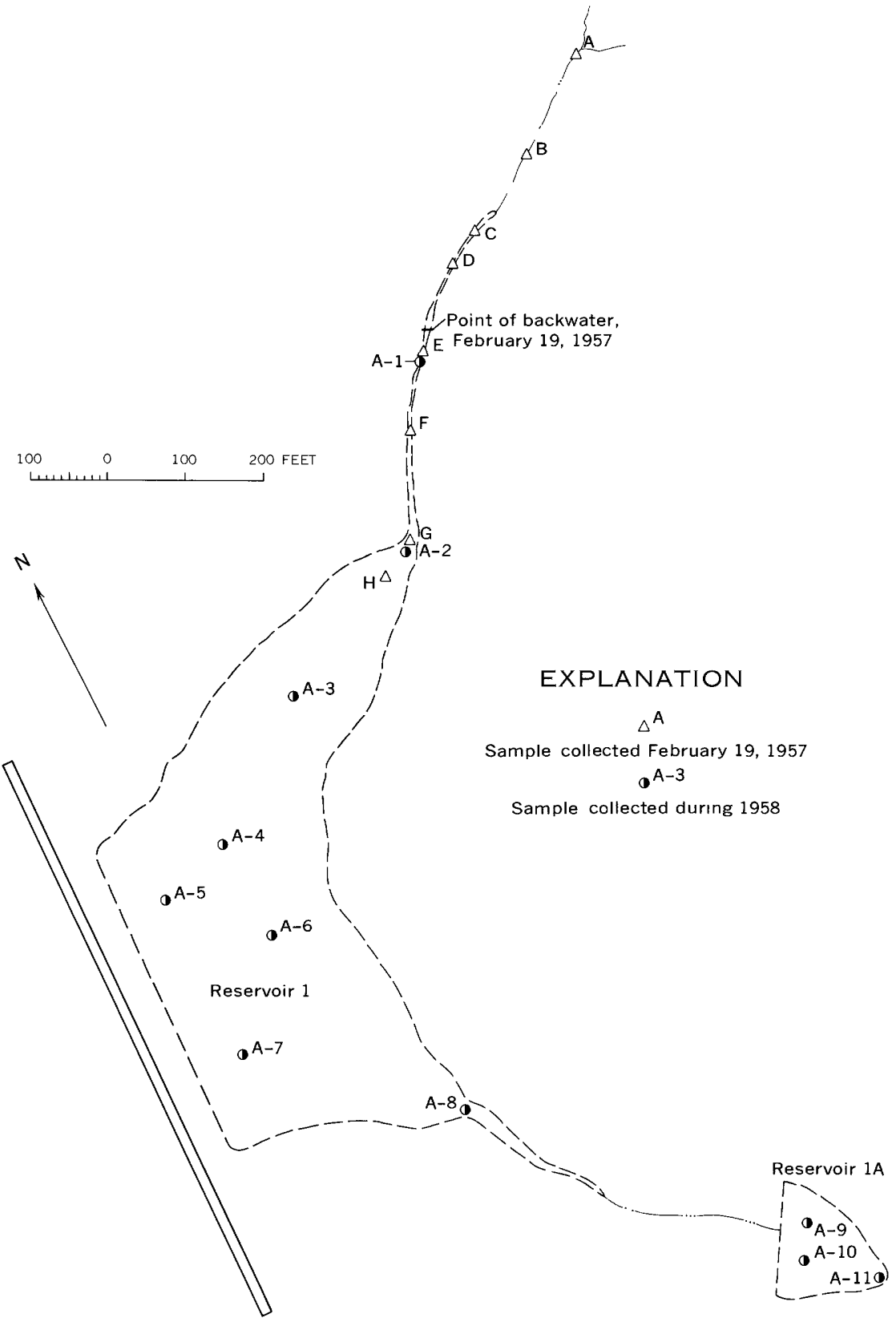

FIGURE 23.-Locations of sampling sections for deposited sediment. 
BROWNELL CREEK SUBWATERSHED No. 1, NEBRASKA C31

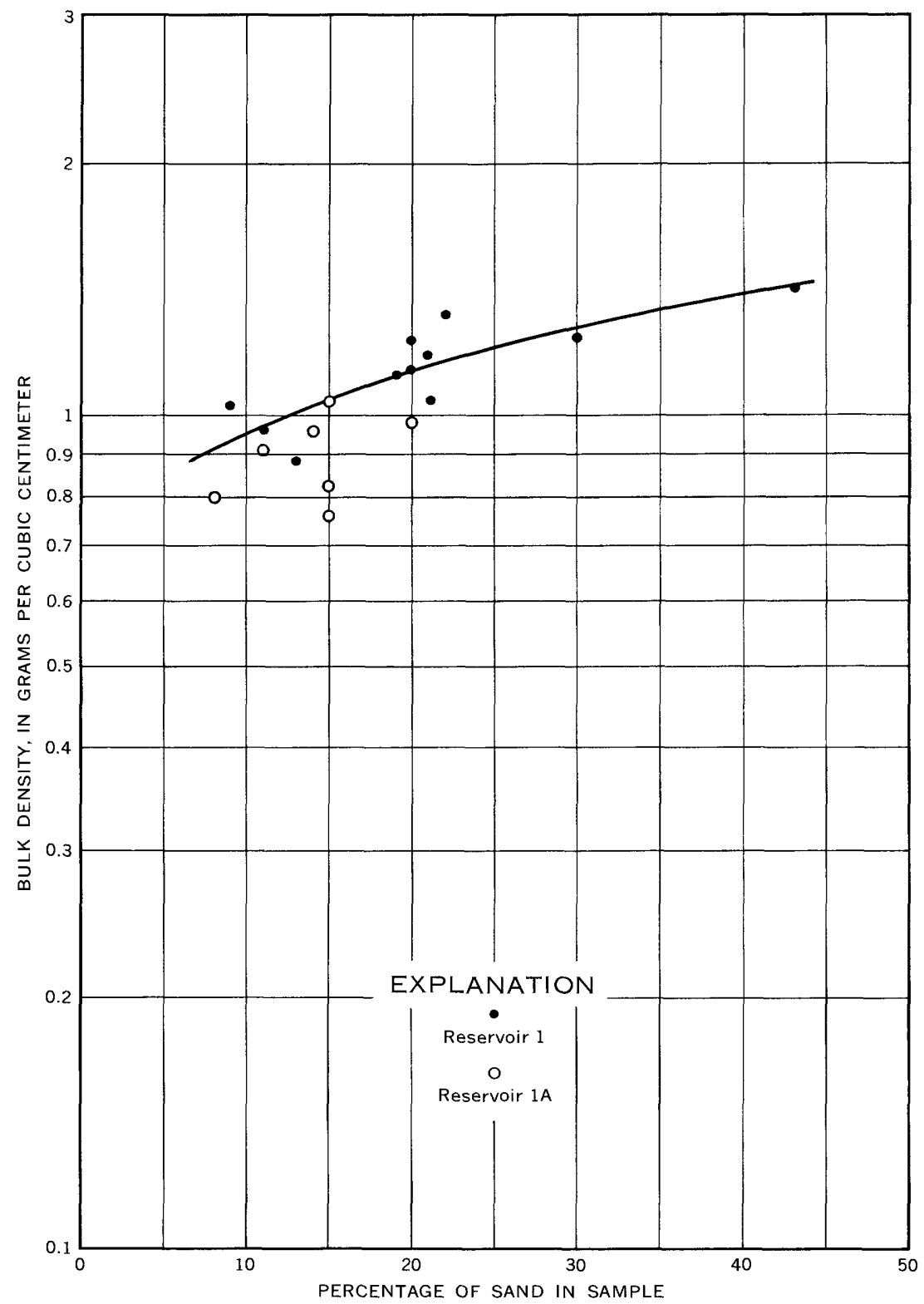

Figure 24.-Relation of bulk density to percentage of sand in deposited sediment. 
deposited sediment was relatively uniform. Upstream from the channel backwater, the material contained a high percentage of sand and some gravel.

Field observations indicate that the extent and particle-size composition of the channel deposits are affected by reservoir stage at the beginning of a runoff period, maximum reservoir stage during a runoff period, characteristics and duration of channel flow, recurrence of minor flows after major flows, and the season in which the flow occurs. An appreciable part of the sediment deposited in channel backwater during high reservoir stages is probably transported as bedload into the reservoir by subsequent minor flows during low reservoir stages.

In April 1957, a composite sample of material from the delta was obtained at the upstream end of reservoir 1A. Particle-size analysis of this sample showed 26 percent silt and clay, 69 percent sand, and 5 percent gravel.

The major source of the transported sand and gravel is probably the glacial till deposits; minor sources are valley alluvium and severely eroding road surfaces and ditches.

A comparison of suspended-sediment size analyses in native water and in distilled water containing a dispersing agent shows that the native water is of such chemical quality as to induce significant flocculation of sediment during quiescent settling in the laboratory; however, flocculation under natural conditions in the reservoir is not necessarily of this same magnitude. Results of chemical analyses of water samples (inflow and outflow) are shown in table 13.

\section{CONCLUSIONS}

The following conclusions resulted from sedimentation investigations that were made in Brownell Creek subwatershed during 1955-59:

1. Average annual runoff in the subwatershed was 3.3 inches.

2. The sediment transported into reservoirs 1 and $1 \mathrm{~A}$ was mostly silt and clay. All the sand and most of the silt and clay that entered reservoir 1 were trapped. The trap efficiency of reservoir 1 , computed from partly estimated data, was between 90 and 95 percent.

3. A large dam, completed upstream from reservoir 1 in 1959 , will reduce the quantity of sediment transported into, and the trap efficiency of, reservoir 1.

4. During 1955-59, about three-fourths of the total sediment discharged from reservoir 1 occurred during seven outflow periods, each of which was less than 5 days in duration. 


\section{BROWNELL CREEK SUBWATERSHED No. 1, NEBRASKA C33}

\section{LITERATURE CITED}

Beesley, T. E., Moran, W. J., Filley, V. W., Pilcher, C. E., and Buzzard, C. R., 1950, Soil Survey, Otoe County, Nebraska : U.S. Dept. Agriculture ser. 1940 , no. $6,87 \mathrm{p}$.

Kohler, M. A., Nordenson, T. J., and Baker, D. R., 1959 Evaporation maps for the United States : U.S. Dept. Commerce Tech. Paper 37, 13 p.

Schumm, S. A., 1956, Evolution of drainage systems and slopes in badlands at Perth Amboy, New Jersey : Geol. Soc. America Bull., v 67, p. 597-646.

Strahler, A. N., 1952, Hypsometric (area-altitude curve) analysis of erosional topography : Geol. Soc. America Bull., v. 63, no. 11, p. 1117-1141. 

TABLES 

BROWNELL CREEK SUBWATERSHED NO. 1, NEBRASKA

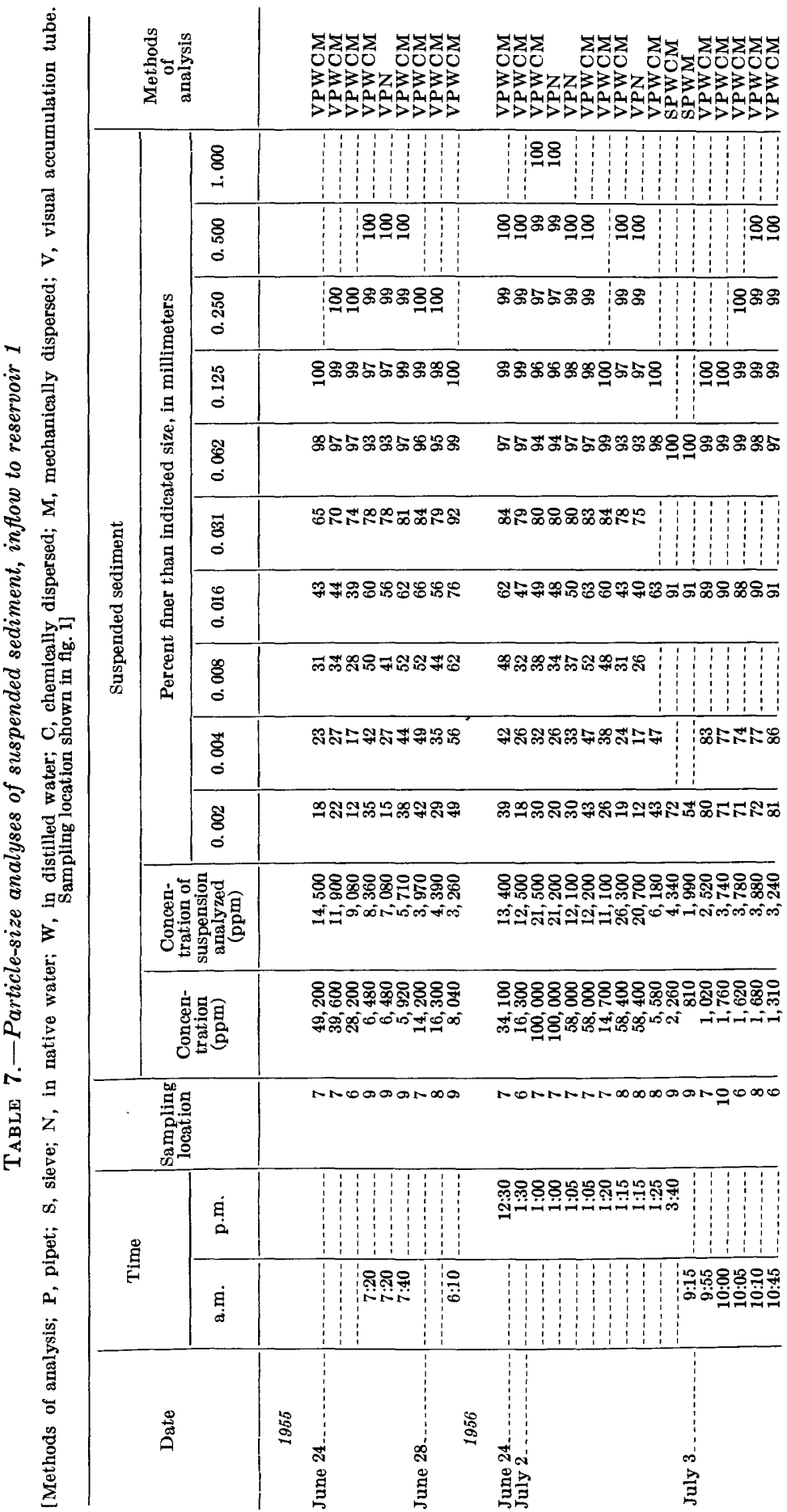




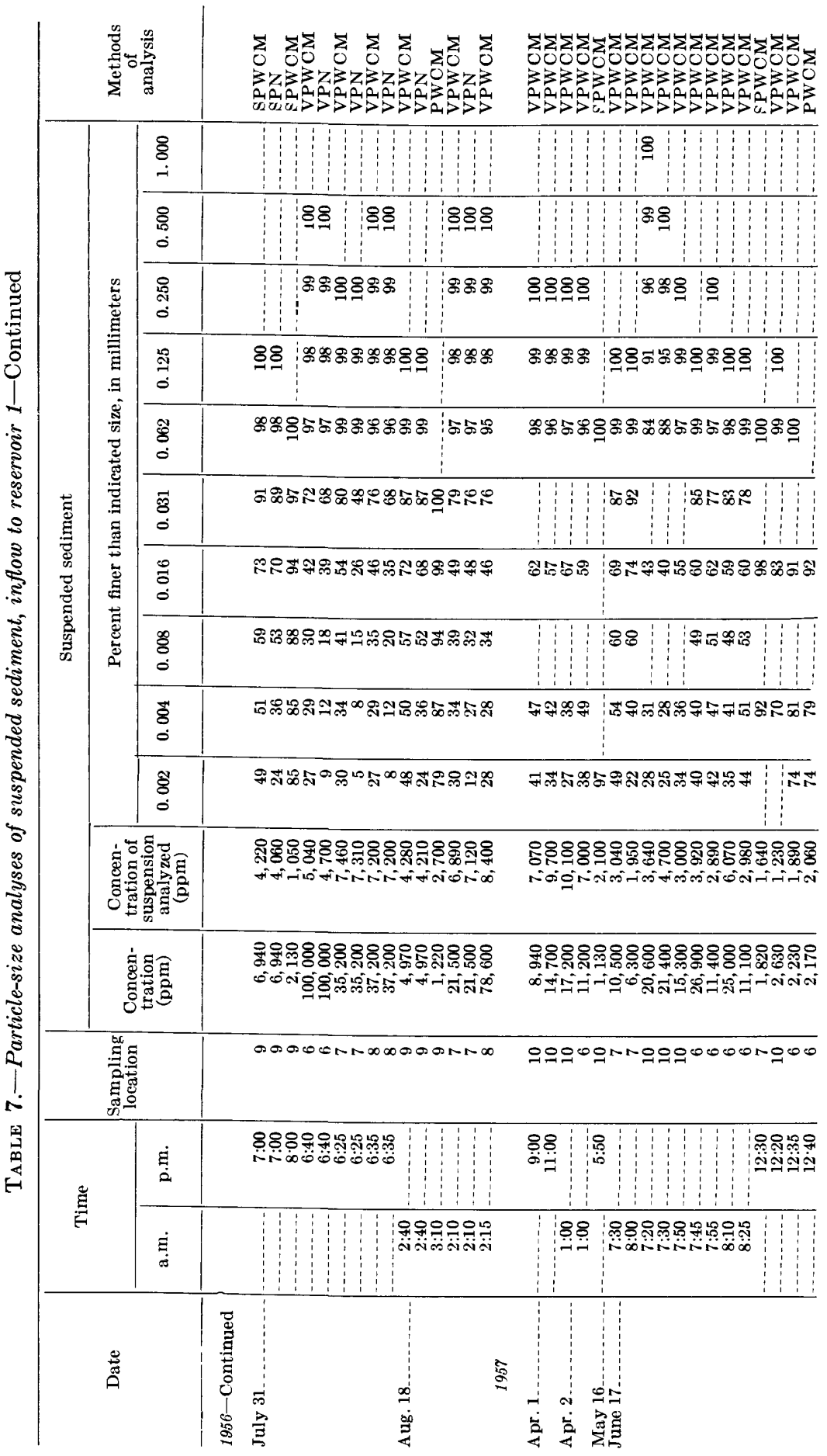




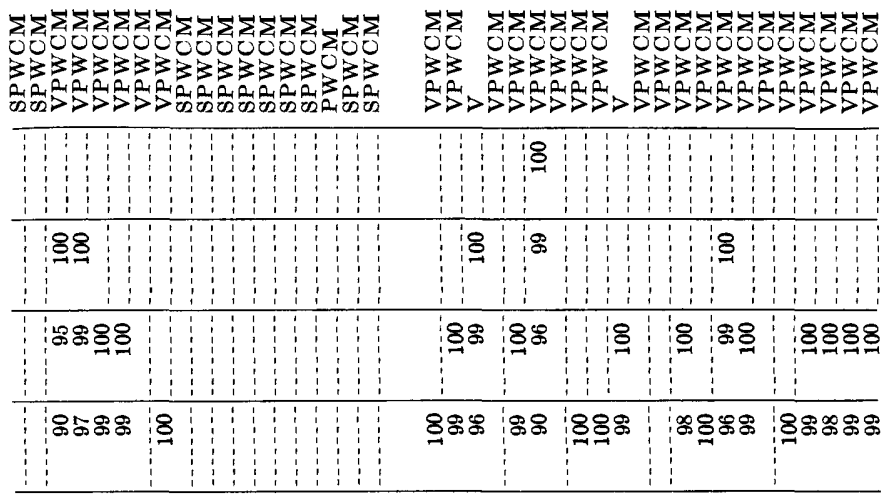

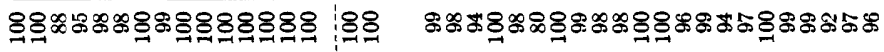

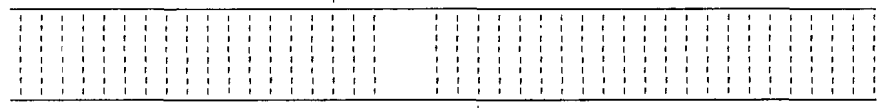

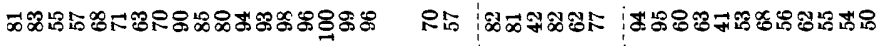

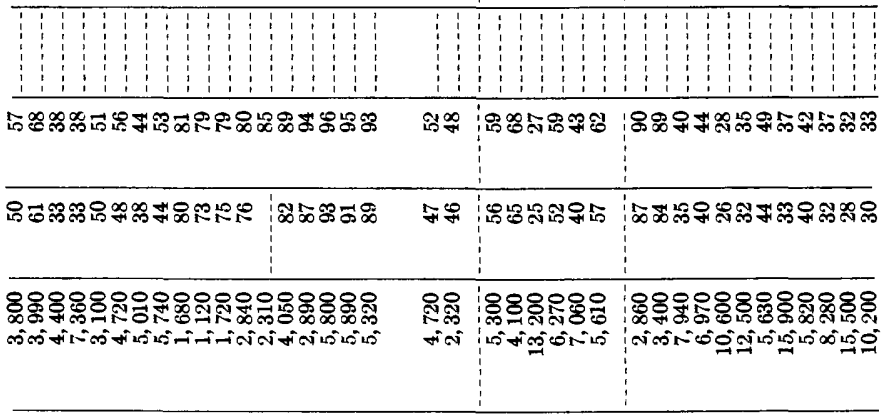

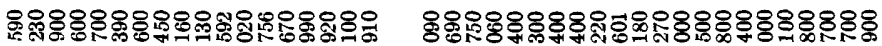

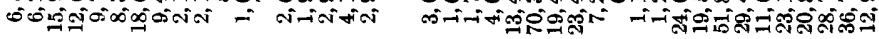

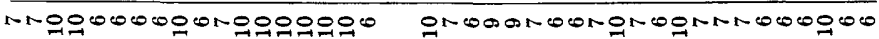

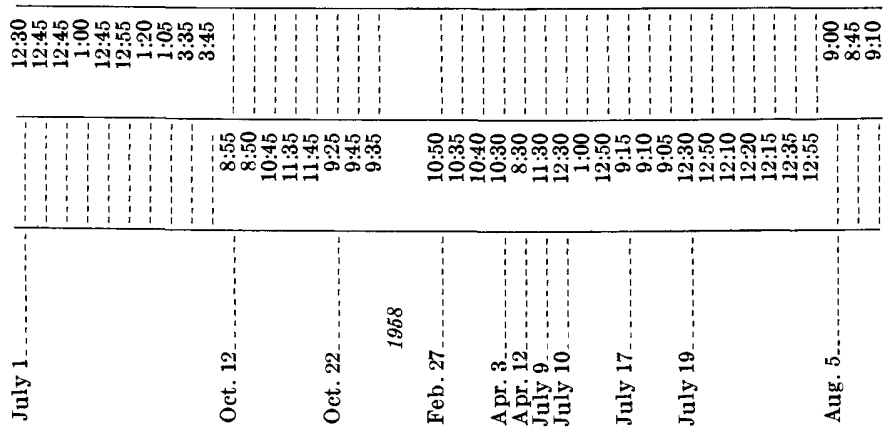




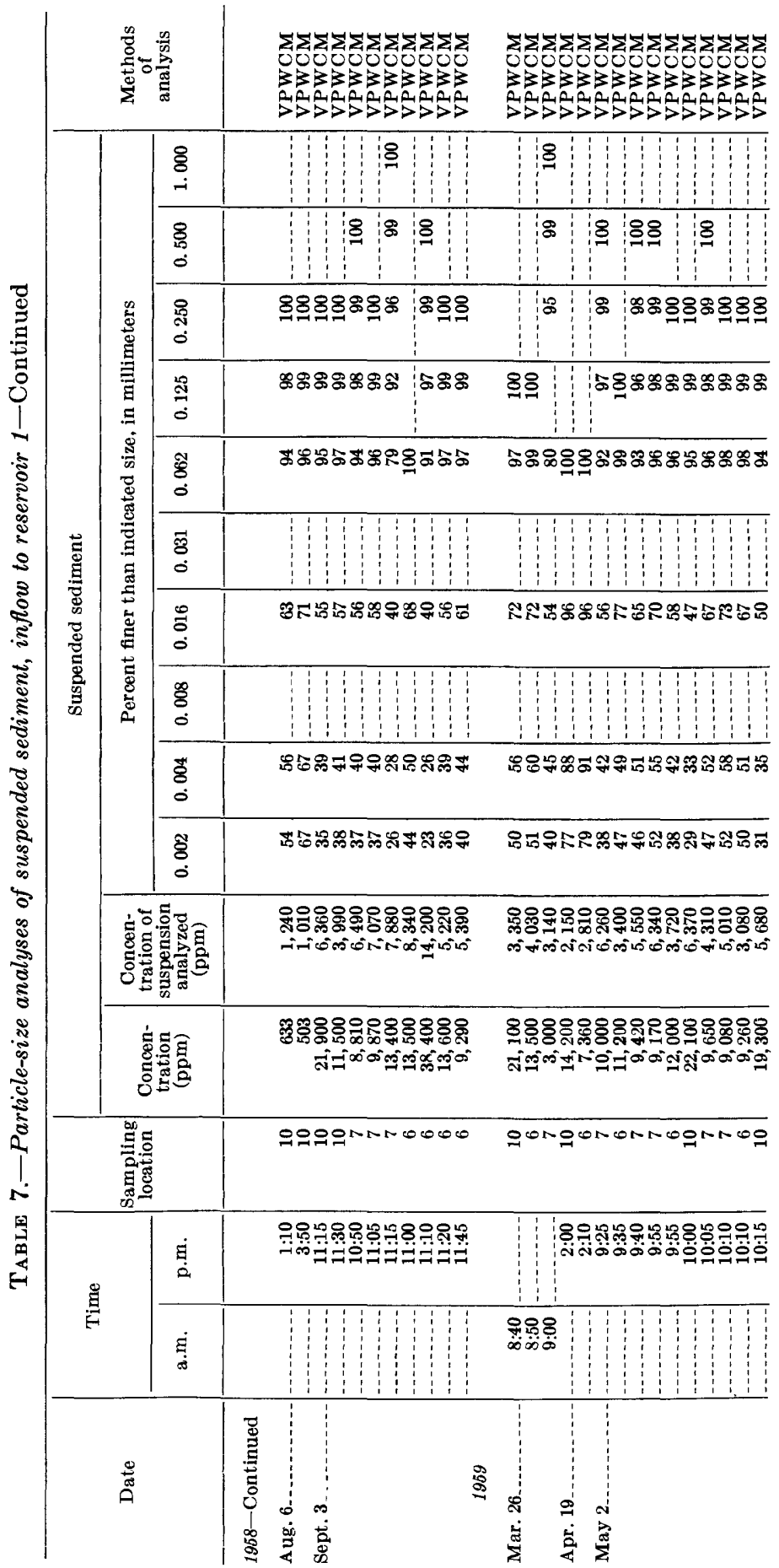




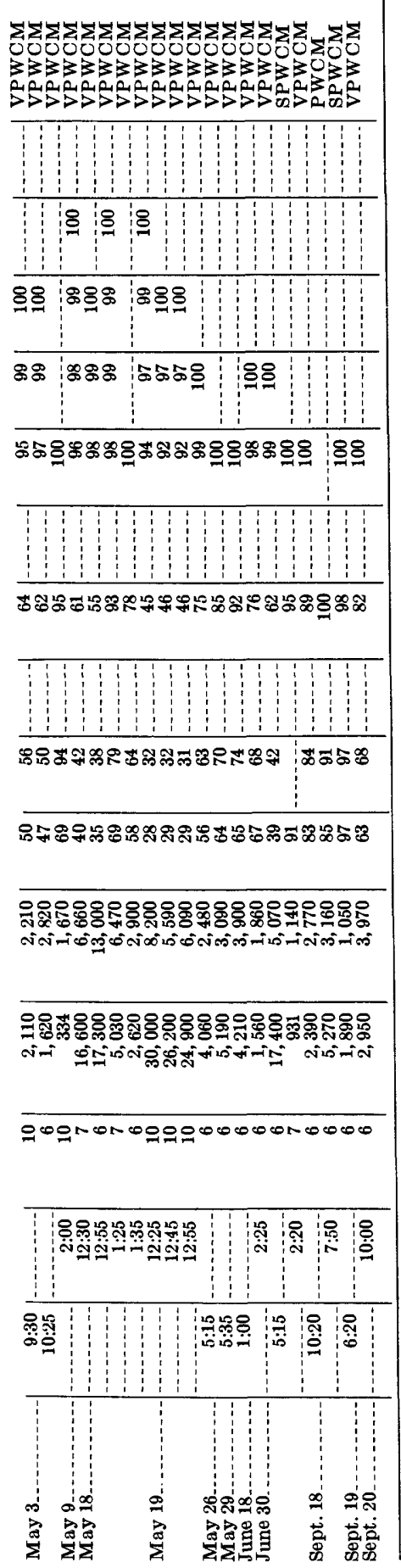




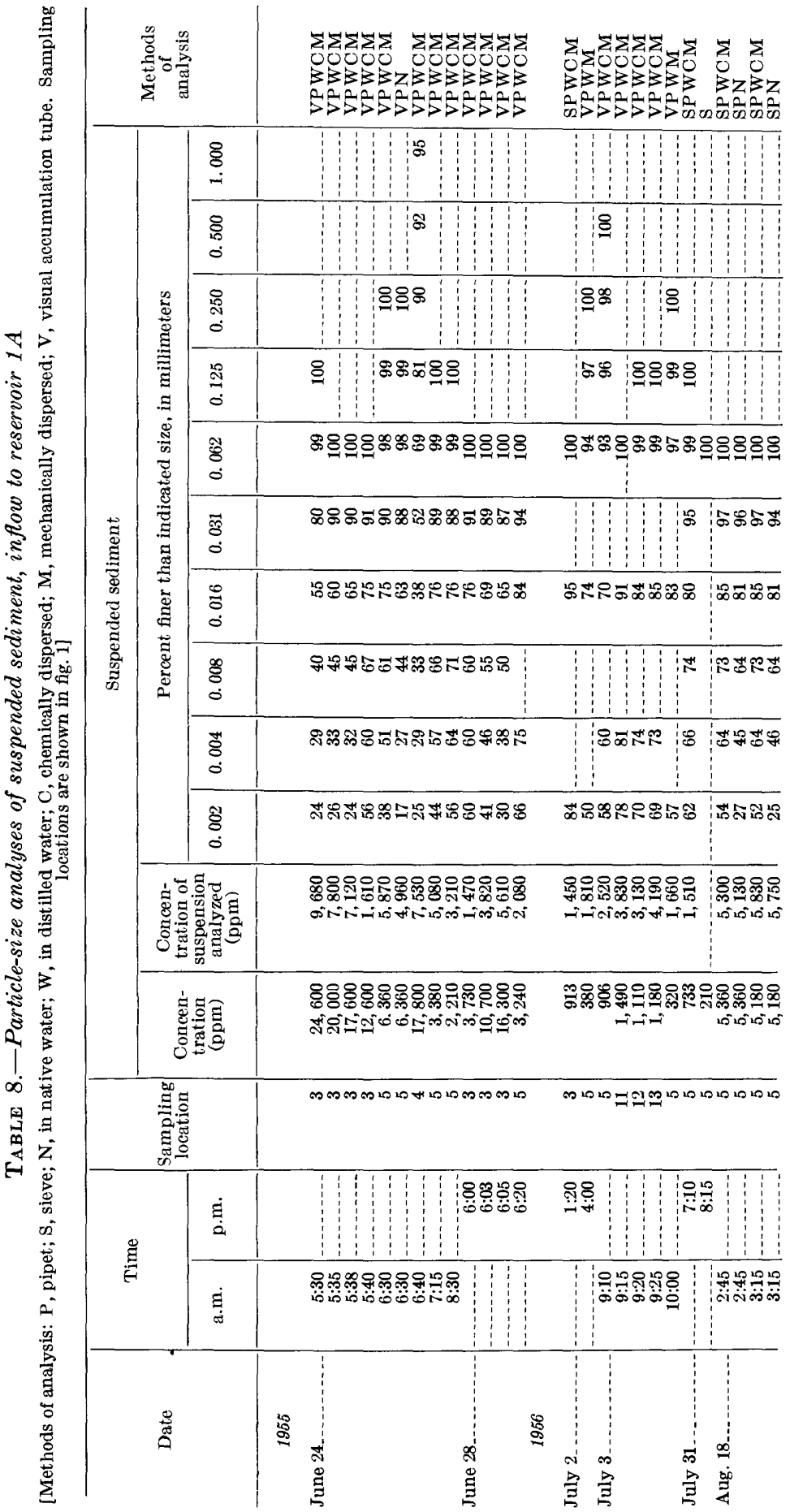


BROWNELL CREEK SUBWATERSHED NO. 1, NEBRASKA C43

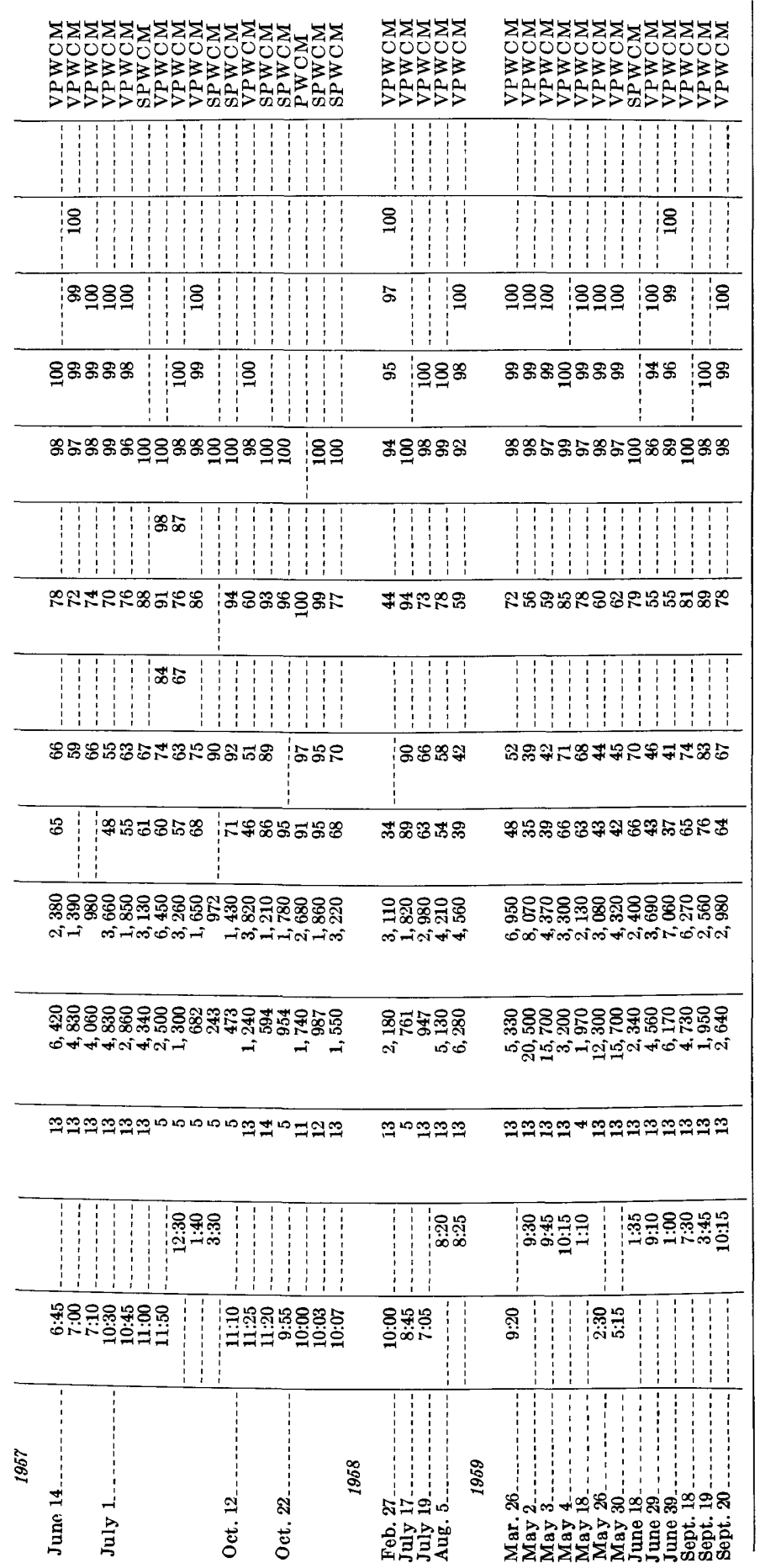




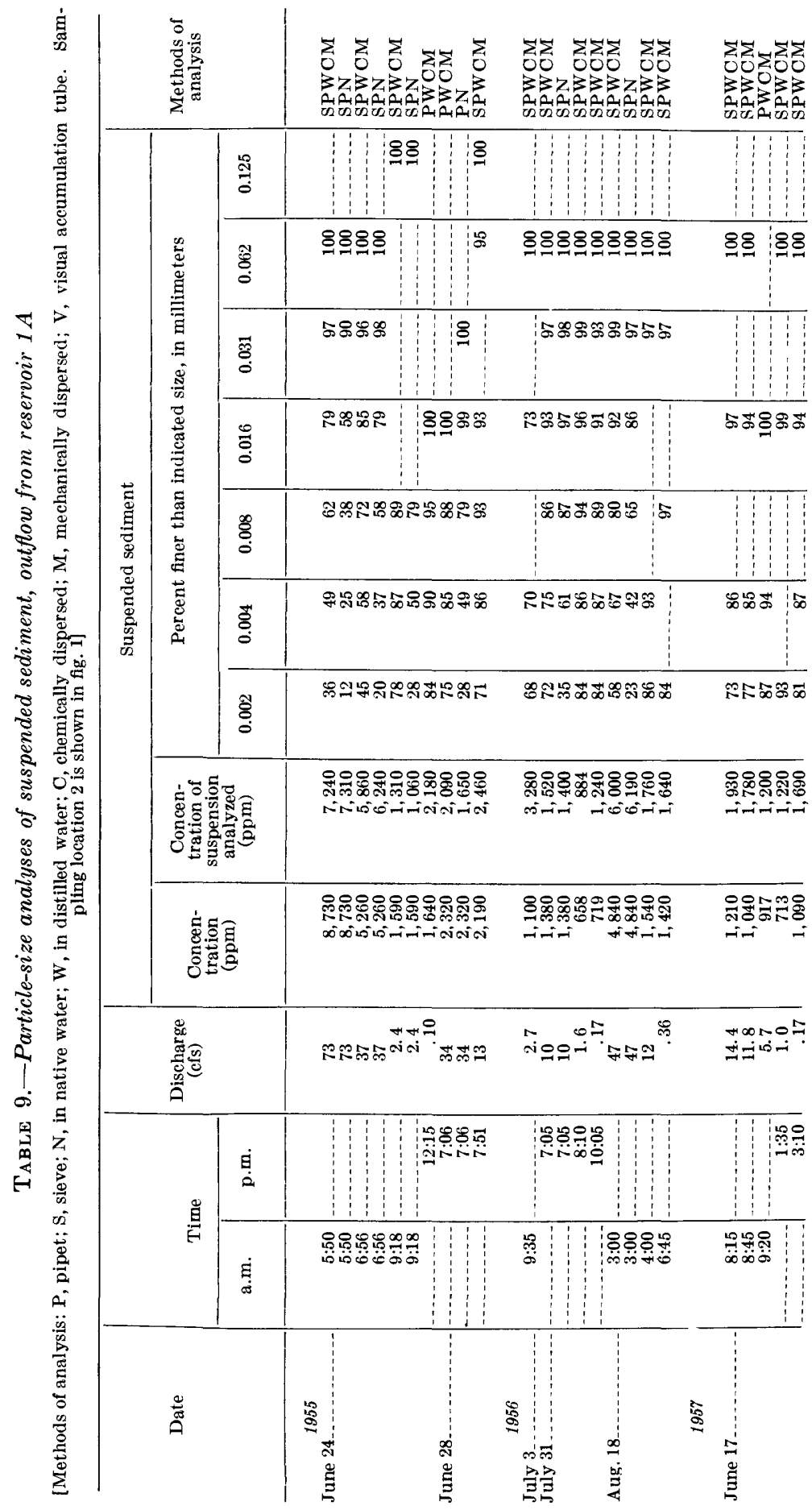




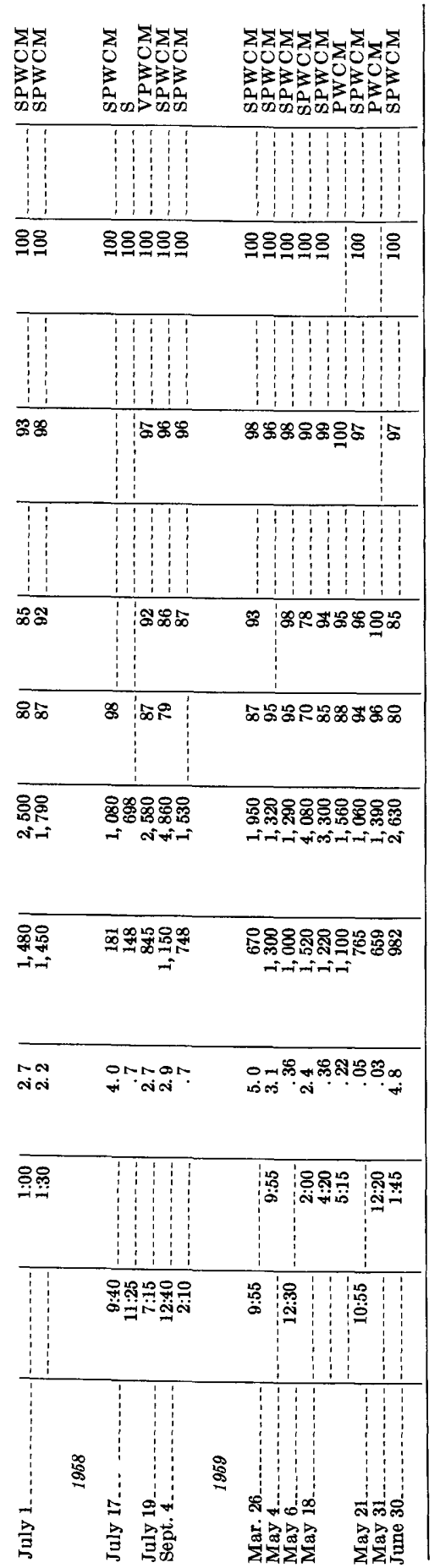




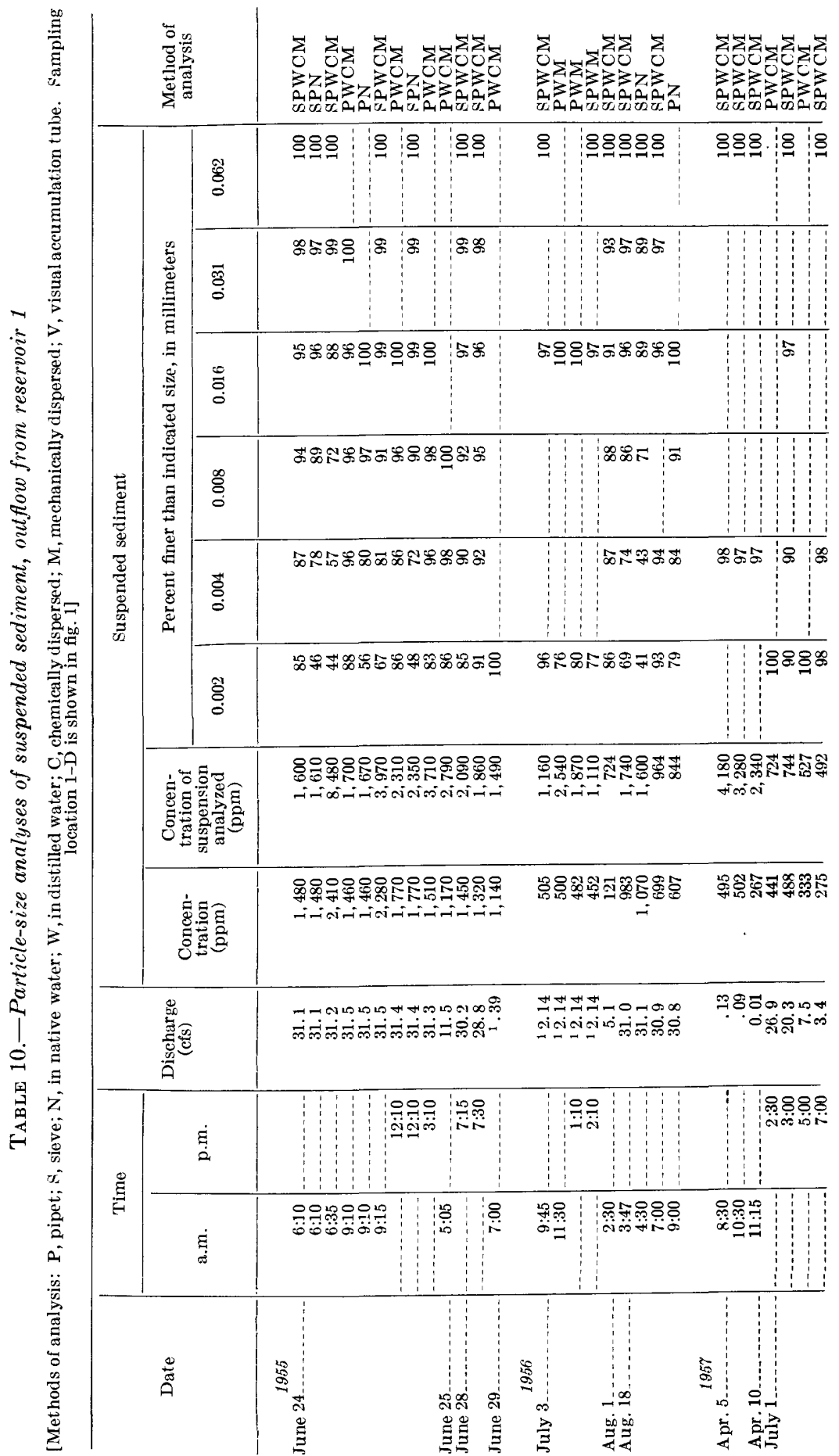


BROWNELL CREEK SUBWATERSHED NO. 1, NEBRASKA C47

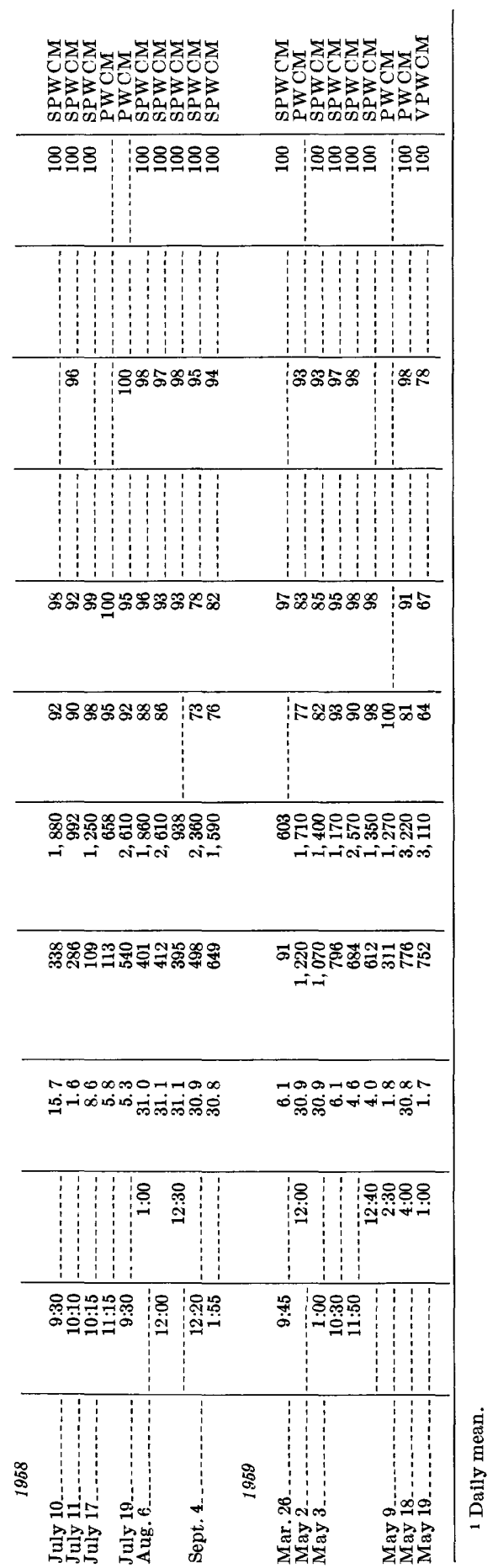


TABLE 11.-Bulk density and particle-size distribution of samples of deposited sediment in reservoirs 1 and $1 A, 1958$

[Data from Agr. Research Service, Lincoln, Nebr.]

\begin{tabular}{|c|c|c|c|c|c|c|c|}
\hline \multirow{2}{*}{ Sampling location } & \multirow{2}{*}{$\begin{array}{c}\text { Depth of sample } \\
\text { below surface } \\
\text { of deposit } \\
\text { (inches) }\end{array}$} & \multirow{2}{*}{$\begin{array}{c}\text { Bulk } \\
\text { density } \\
\text { (g per cc) }\end{array}$} & \multicolumn{5}{|c|}{$\begin{array}{l}\text { Percentage finer than indicated size, } \\
\text { in millimeters }\end{array}$} \\
\hline & & & 0.002 & 0.005 & 0.020 & 0.050 & 2.000 \\
\hline \multirow[t]{4}{*}{$A-1 \ldots \ldots$} & $2-5$ & 1. 15 & & & & & \\
\hline & $5-9$ & 1. 19 & 31 & 31 & 54 & 79 & 100 \\
\hline & $\begin{array}{r}9-13 \\
13-17\end{array}$ & $\begin{array}{l}1.30 \\
1.11\end{array}$ & 35 & 37 & 56 & 81 & 100 \\
\hline & $17-21$ & 1. 30 & & & & & \\
\hline \multirow[t]{2}{*}{$A-2$} & $\begin{array}{l}2-6 \\
6-10\end{array}$ & .89 & 33 & 34 & 57 & 87 & 100 \\
\hline & $\begin{array}{r}0-10 \\
10-14\end{array}$ & 1. 25 & 29 & 30 & 51 & 70 & 100 \\
\hline A-3 & $\begin{array}{c}14-18 \\
1-4\end{array}$ & $\begin{array}{l}\text { 1. } 32 \\
\text { 1. } 23\end{array}$ & $-\overline{3}$ & $-\overline{38}$ & 59 & 80 & 100 \\
\hline \multirow{2}{*}{$\mathrm{A}-4 \ldots \ldots$} & $\begin{array}{l}4-8 \\
1-4\end{array}$ & $\begin{array}{l}1.36 \\
1.42\end{array}$ & 23 & 24 & 41 & 57 & 100 \\
\hline & $4-8$ & 1. 51 & & & & & 10 \\
\hline \multirow[t]{2}{*}{$A-5$} & $1-4$ & .88 & & & & & \\
\hline & $\begin{array}{l}4-8 \\
1-5\end{array}$ & $\begin{array}{r}97 \\
80\end{array}$ & 40 & 43 & 70 & 89 & 100 \\
\hline \multirow{2}{*}{$\mathrm{A}-6$} & $5-9$ & 1. 05 & 34 & 35 & 58 & 79 & 100 \\
\hline & $9-13$ & 1. 14 & & & & & \\
\hline$A-7$ & $1-3$ & 1.03 & 38 & 43 & 70 & 91 & 100 \\
\hline \multirow[t]{2}{*}{ A-8 8} & $\begin{array}{l}2-5 \\
5-8\end{array}$ & $\begin{array}{l}\text { 1. } 14 \\
\text { 1. } 21\end{array}$ & 33 & 34 & 59 & 80 & 100 \\
\hline & $\begin{array}{l}8-12 \\
2-7\end{array}$ & 1. 32 & 33 & 34 & 57 & 78 & 100 \\
\hline \multirow{2}{*}{$A-9$} & $8-12$ & $\begin{array}{l}.01 \\
.96\end{array}$ & 31 & 31 & 57 & 86 & 100 \\
\hline & $\begin{array}{l}12-16 \\
19-23\end{array}$ & $\begin{array}{l}.86 \\
1.04\end{array}$ & 27 & 29 & 54 & 85 & 100 \\
\hline \multirow[t]{2}{*}{ A-10 } & $\begin{array}{c}25-29 \\
3-7\end{array}$ & $\begin{array}{l}.85 \\
.80\end{array}$ & 46 & 50 & 75 & $9 \overline{2}$ & 100 \\
\hline & $\begin{array}{l}12-16 \\
16-20\end{array}$ & $\begin{array}{l}.89 \\
.83\end{array}$ & 38 & 39 & 64 & $8 \overline{5}$ & 100 \\
\hline \multirow[t]{4}{*}{ A-11 } & $\begin{array}{c}20-24 \\
2-6\end{array}$ & $\begin{array}{l}.70 \\
.76\end{array}$ & 29 & 33 & 54 & 85 & 100 \\
\hline & $\begin{array}{r}7-11 \\
11-15\end{array}$ & $\begin{array}{l}.98 \\
.91\end{array}$ & 40 & 40 & 66 & 89 & 100 \\
\hline & $15-19$ & 1. 02 & & & & & \\
\hline & $19-23$ & .99 & 33 & 35 & 57 & 80 & 100 \\
\hline
\end{tabular}

TABLE 12.-Particle-size distribution of deposited-sediment samples in channel and in reservoir 1, Feb. 19, 1957

[Sampling locations shown in fig. 23]

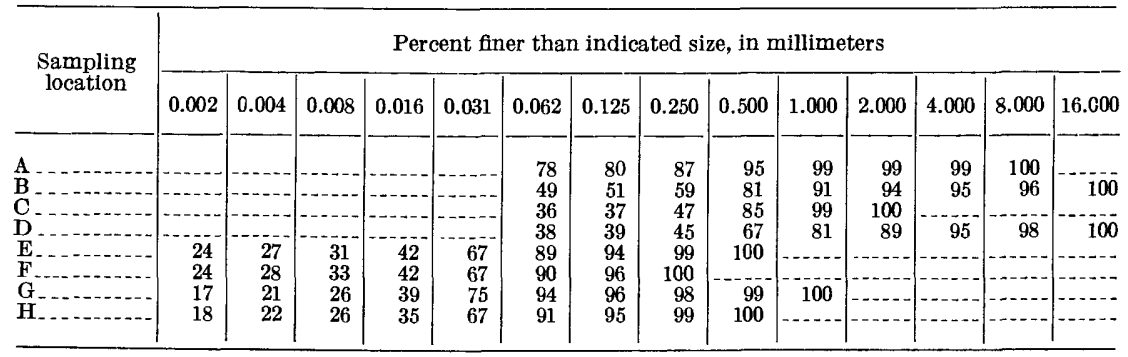


BROWNELL CREEK SUBWATERSHED No. 1, NEBRASKA C49

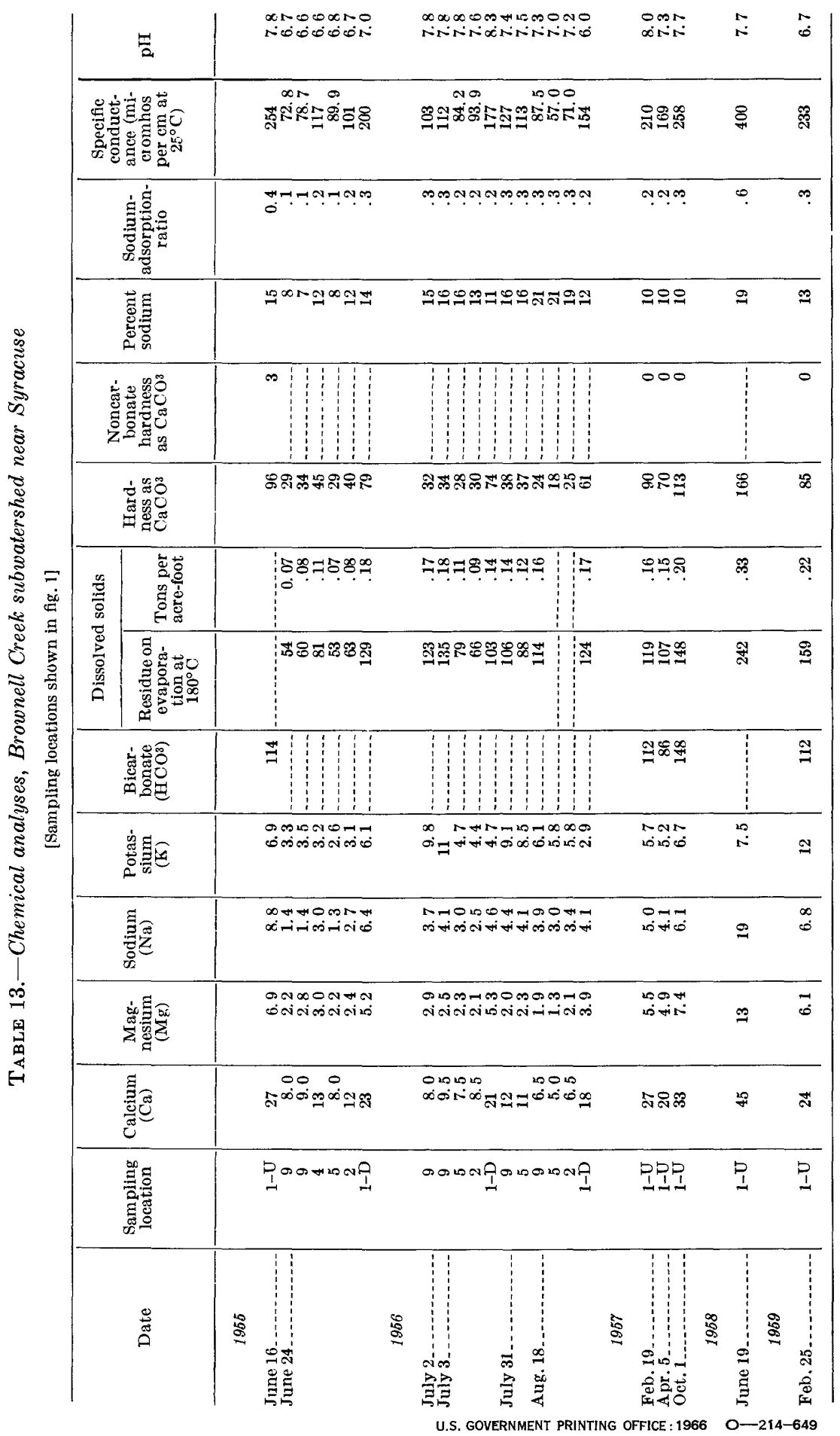

